
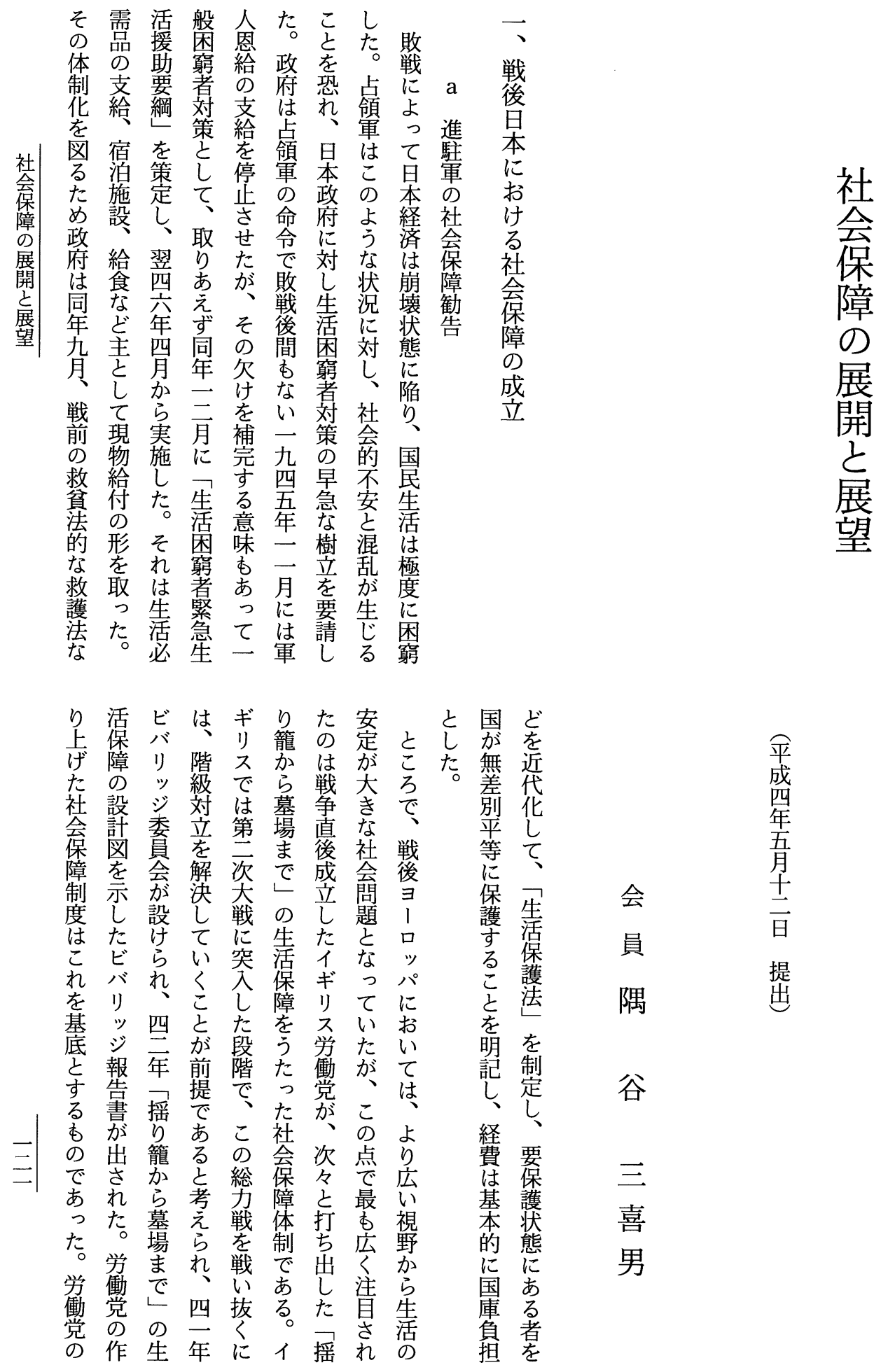


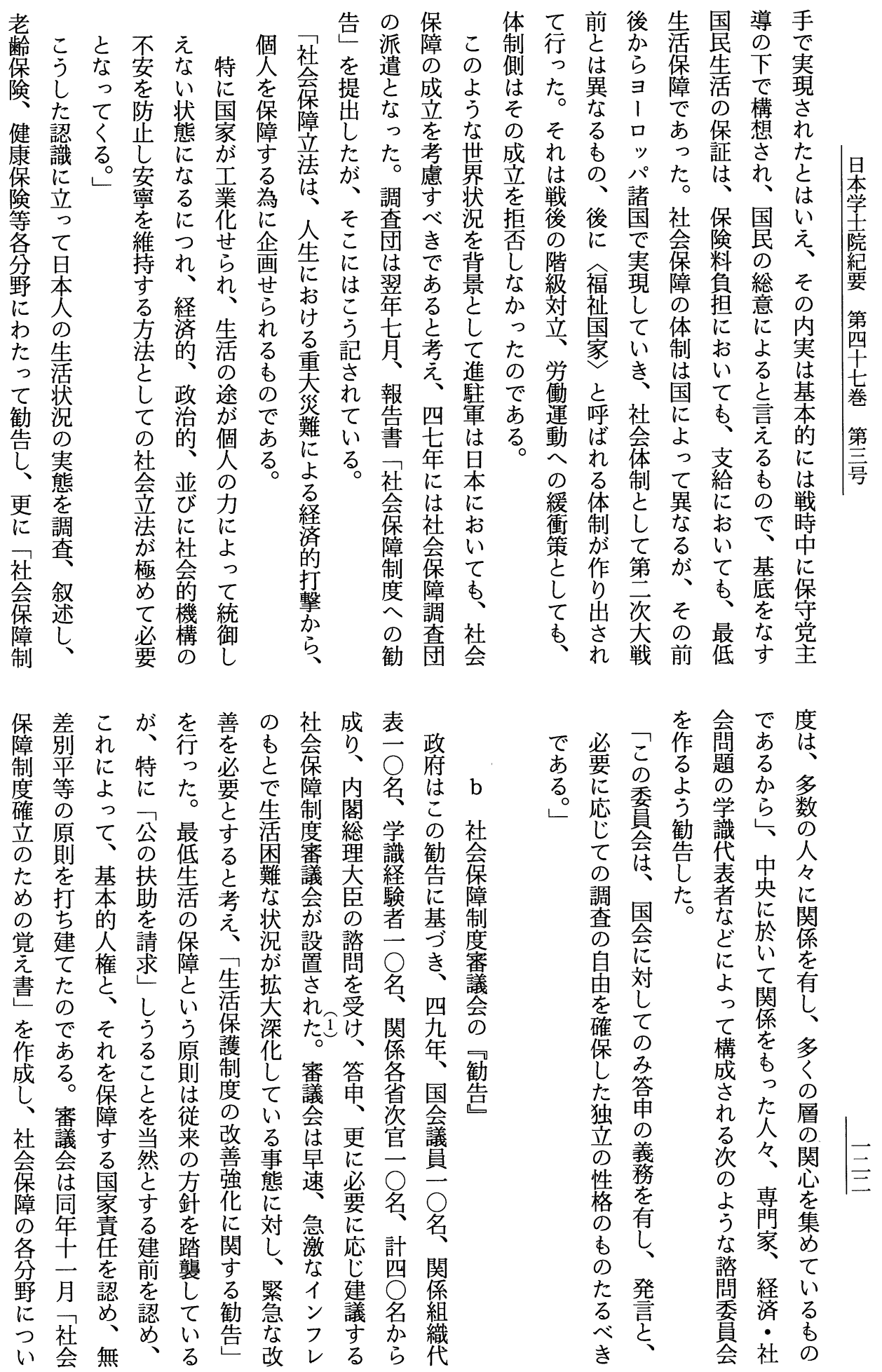




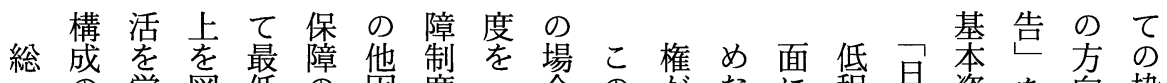

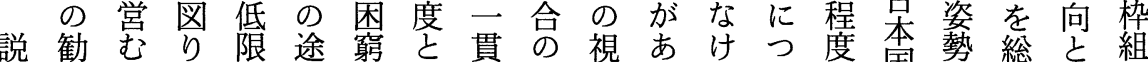

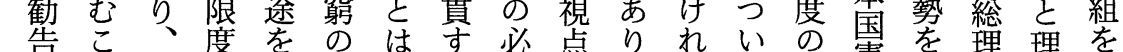

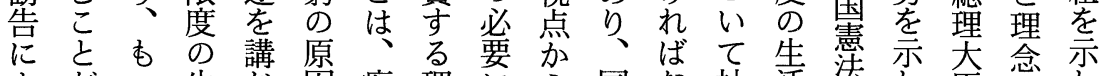

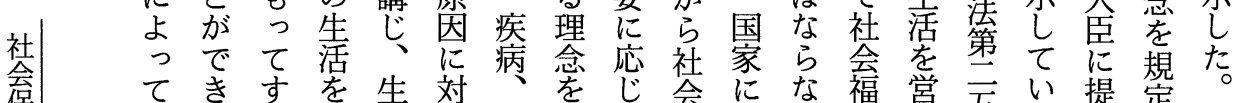

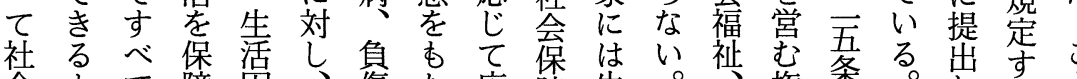

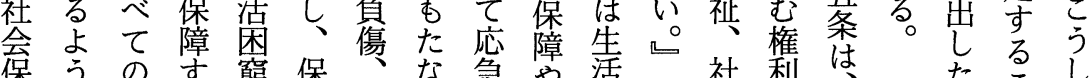

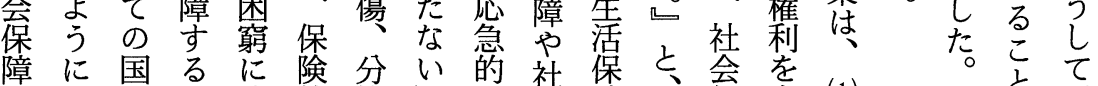

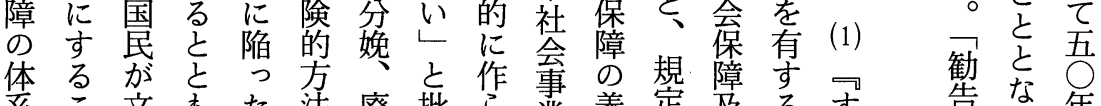

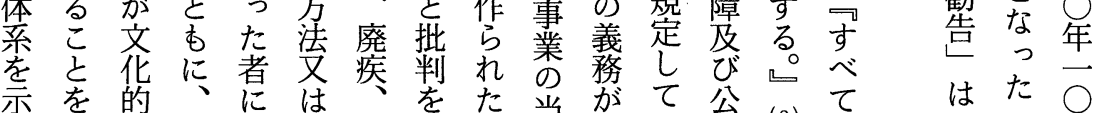

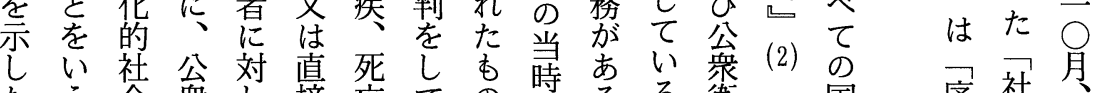

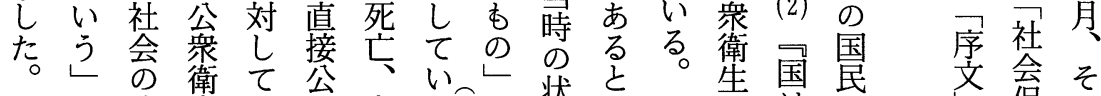

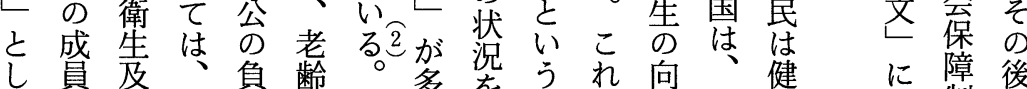

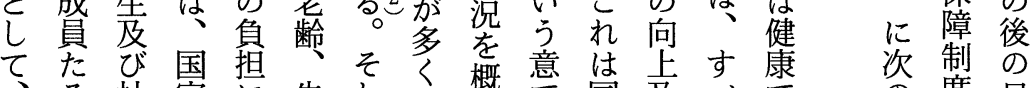

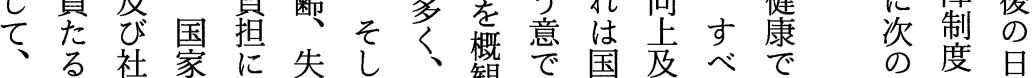

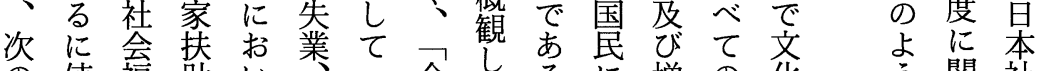
の值福助い米全し るに増の花う関社

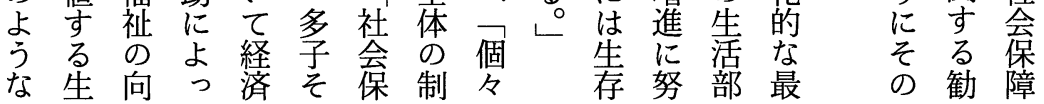

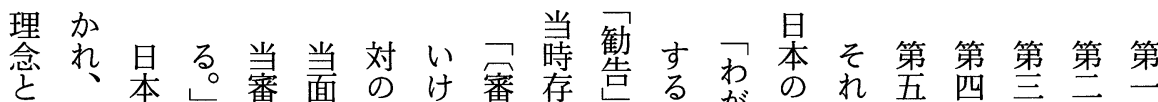

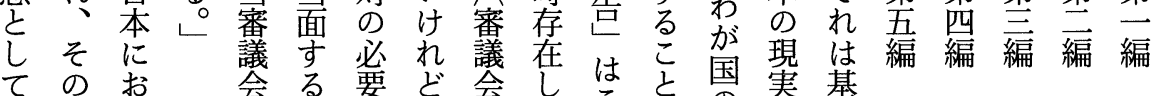

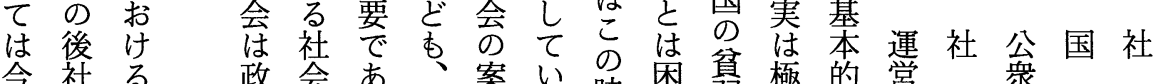

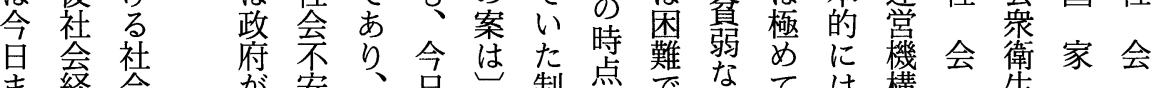

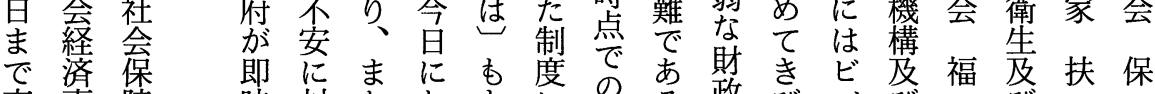

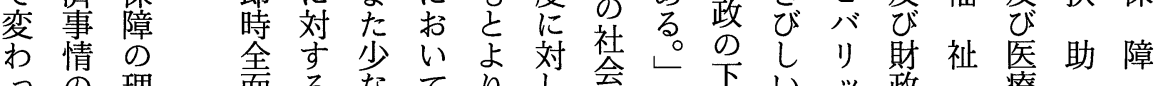

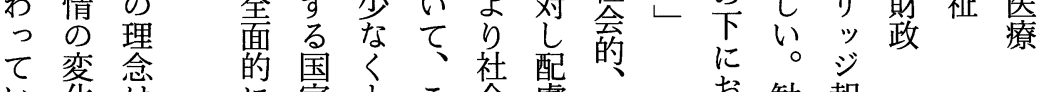

い化は嫁とこ会慮経敃篗

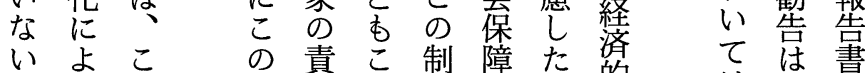

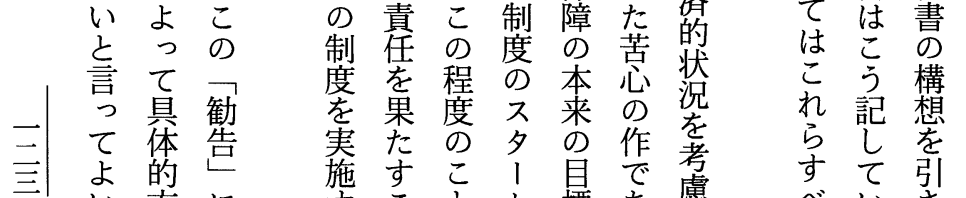

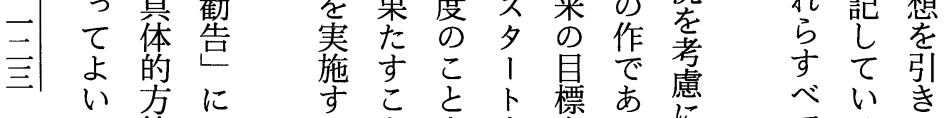

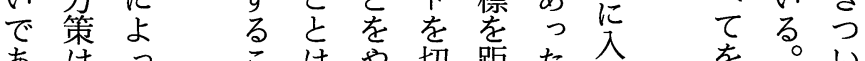

あはっこはや切距た政をるい

う発て 基稂ぎら る

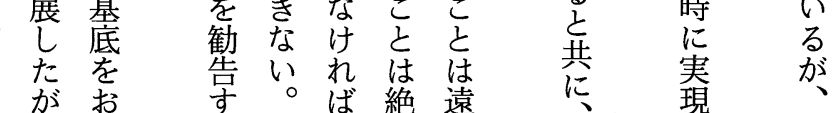



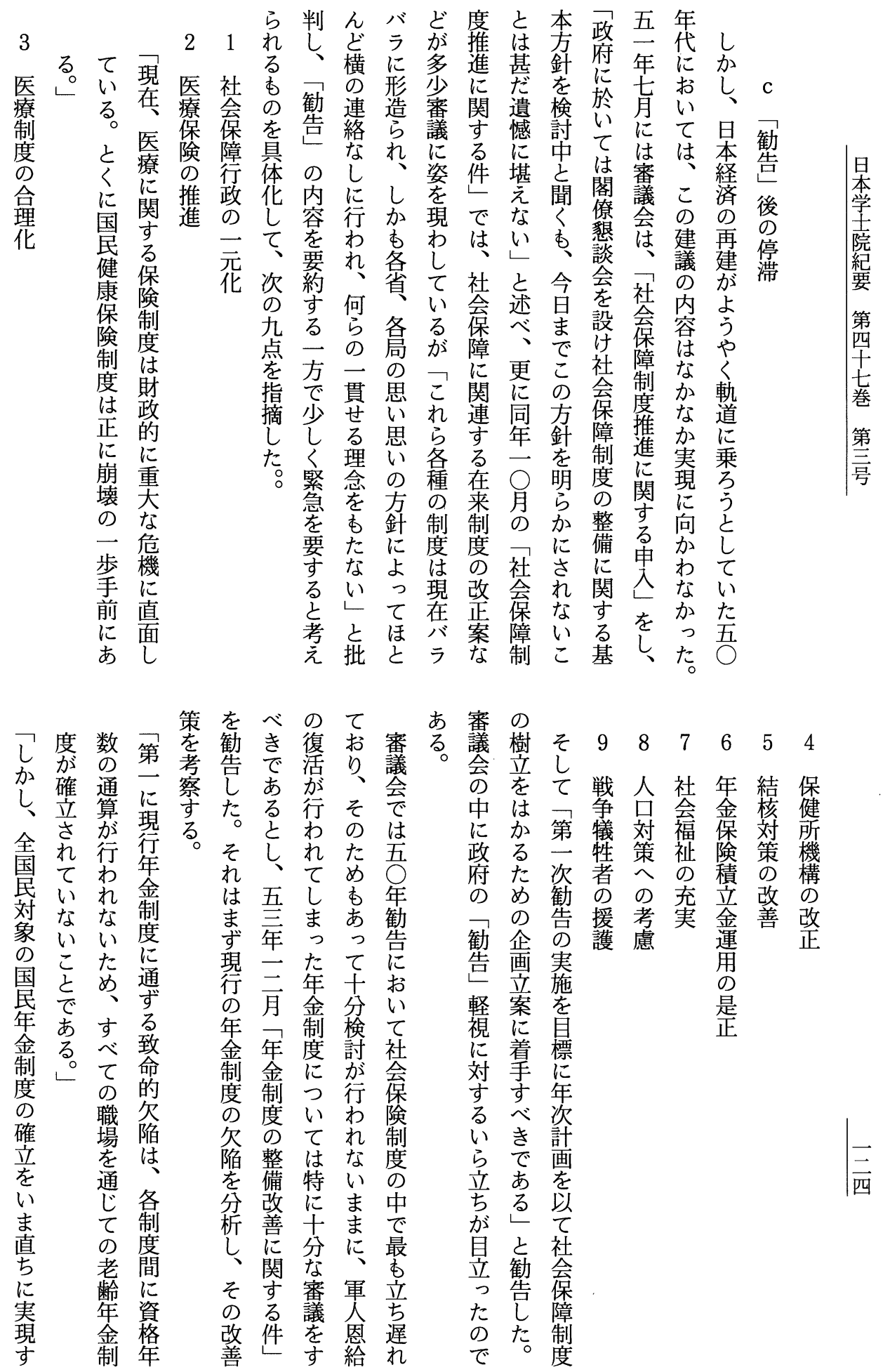

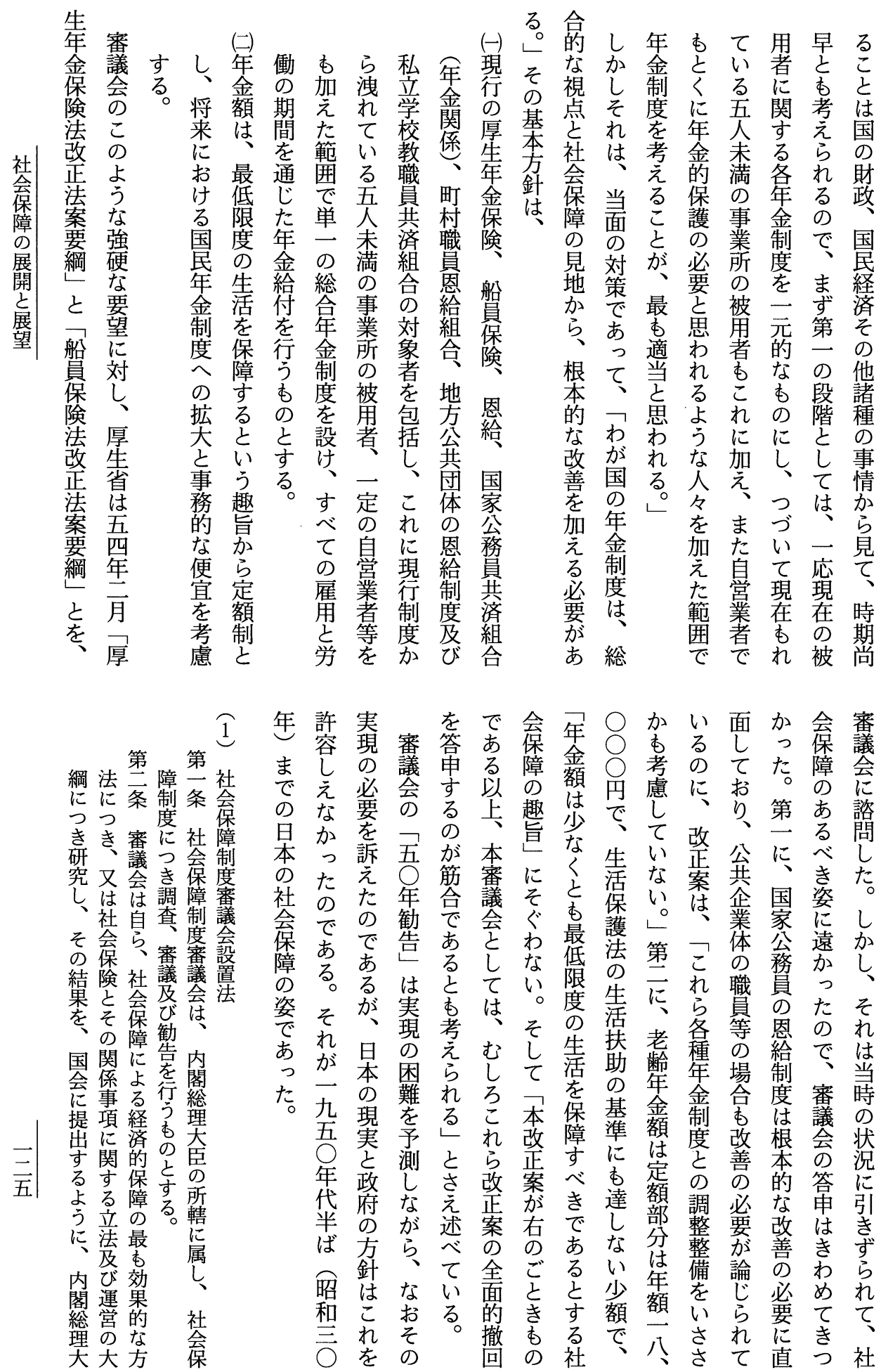

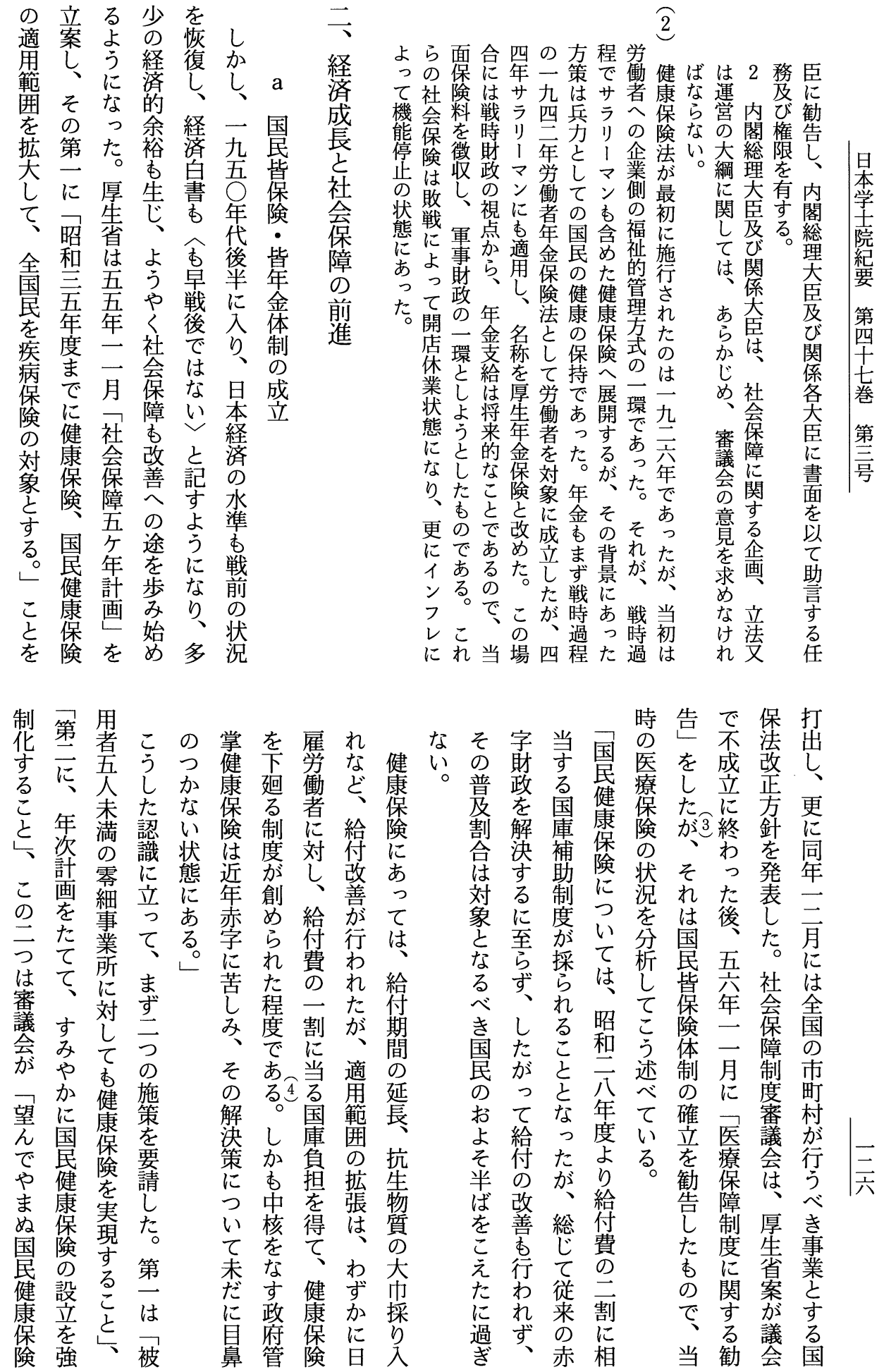
で陥の度済切給用定き険五関康的〈家付へ

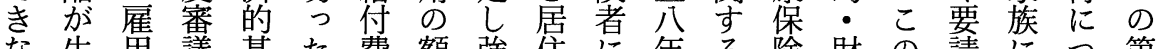
な生角議基た費額強住に年る険財の請につ第

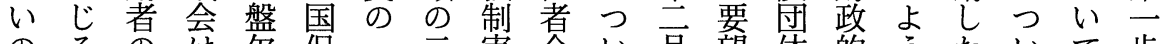
のるの炎保二言寒㝨い望体的うたいて点

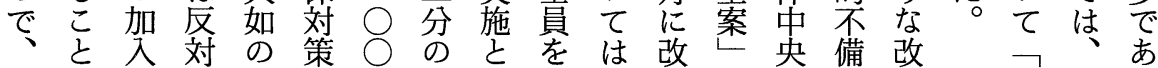

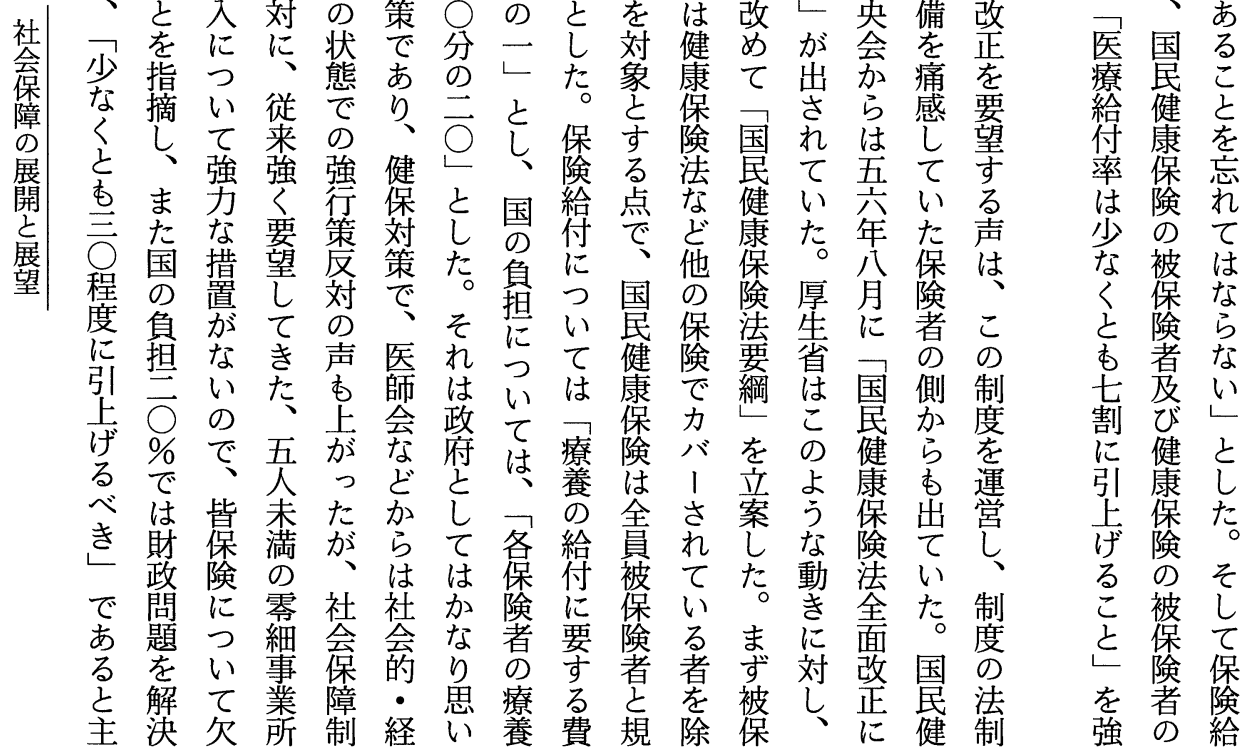

加即年よ費め保社し金な活大年保あ村が張

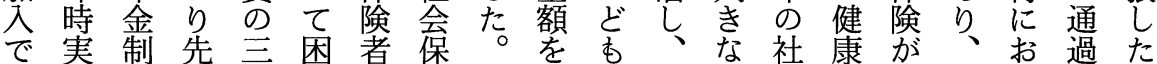
き赛制先言困者保こ定次公閵保保現そ礼過た

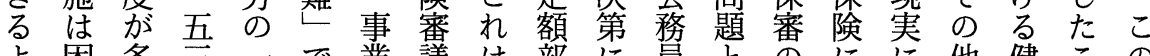
よ困多至二で業議は部に員とのにに他健この う難岐年をあ主会経分重のな対成の康とよ にとに末負るのは営と要恩ら勧し立実保にう すし 分号担加負五陣報性給な告年し施険よな るて事立年守ら担四学酬増問っでは金た義縝り替

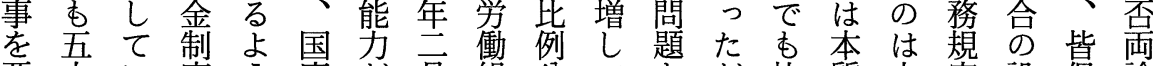
要人い度う庫が月組分てと媲六定設保論 望未るの建負殆口合汃来な、較的一立立険の し 満の整議担ど財をらたり講的に年四等の中 たのを備しに限源まな。始和軽長四月は体で 事三䩦たよ度をきる厚め条視期月二六制五 政業元革。るに保込之生、約さ的で日一は公 府所化社他達険え省更がれなあ施年い年 一 はの卞に会なし料でるはに成問っ行言ち士

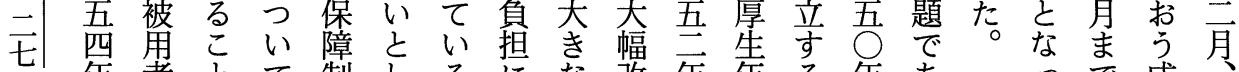
年. 者とて制しるにな改年年る年あるっで成

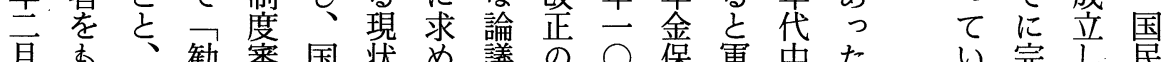

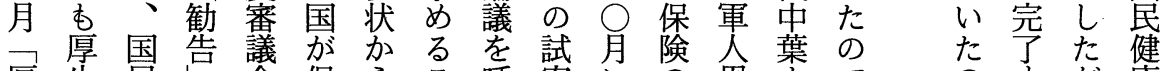

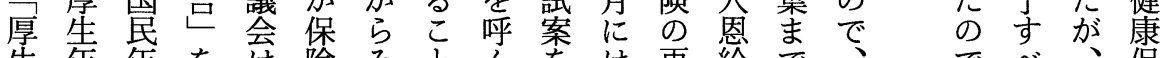

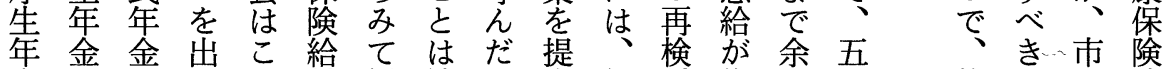

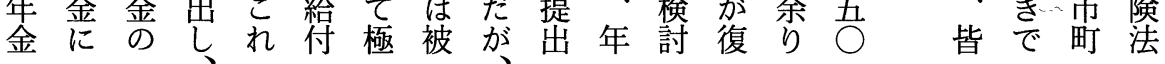



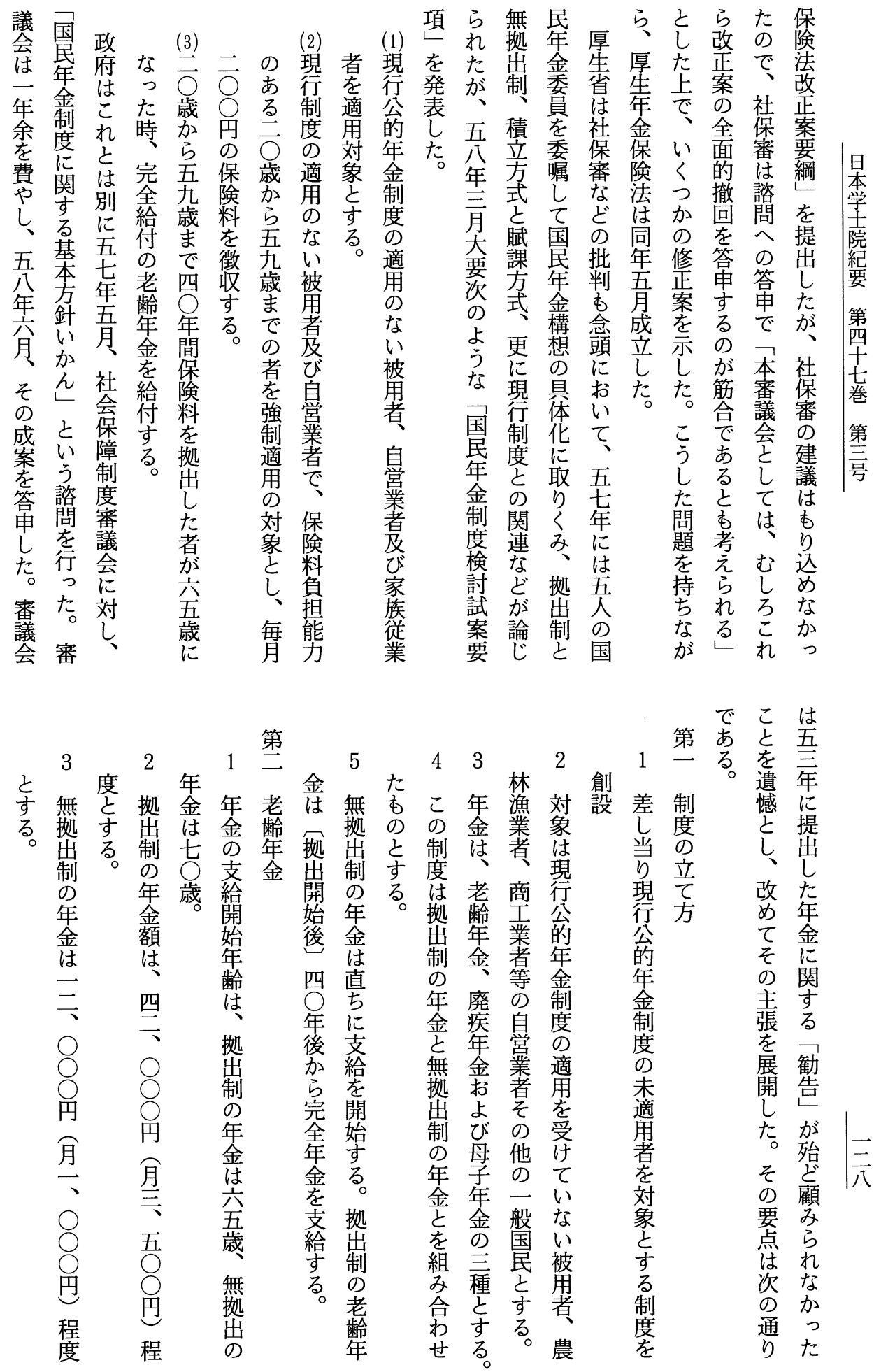

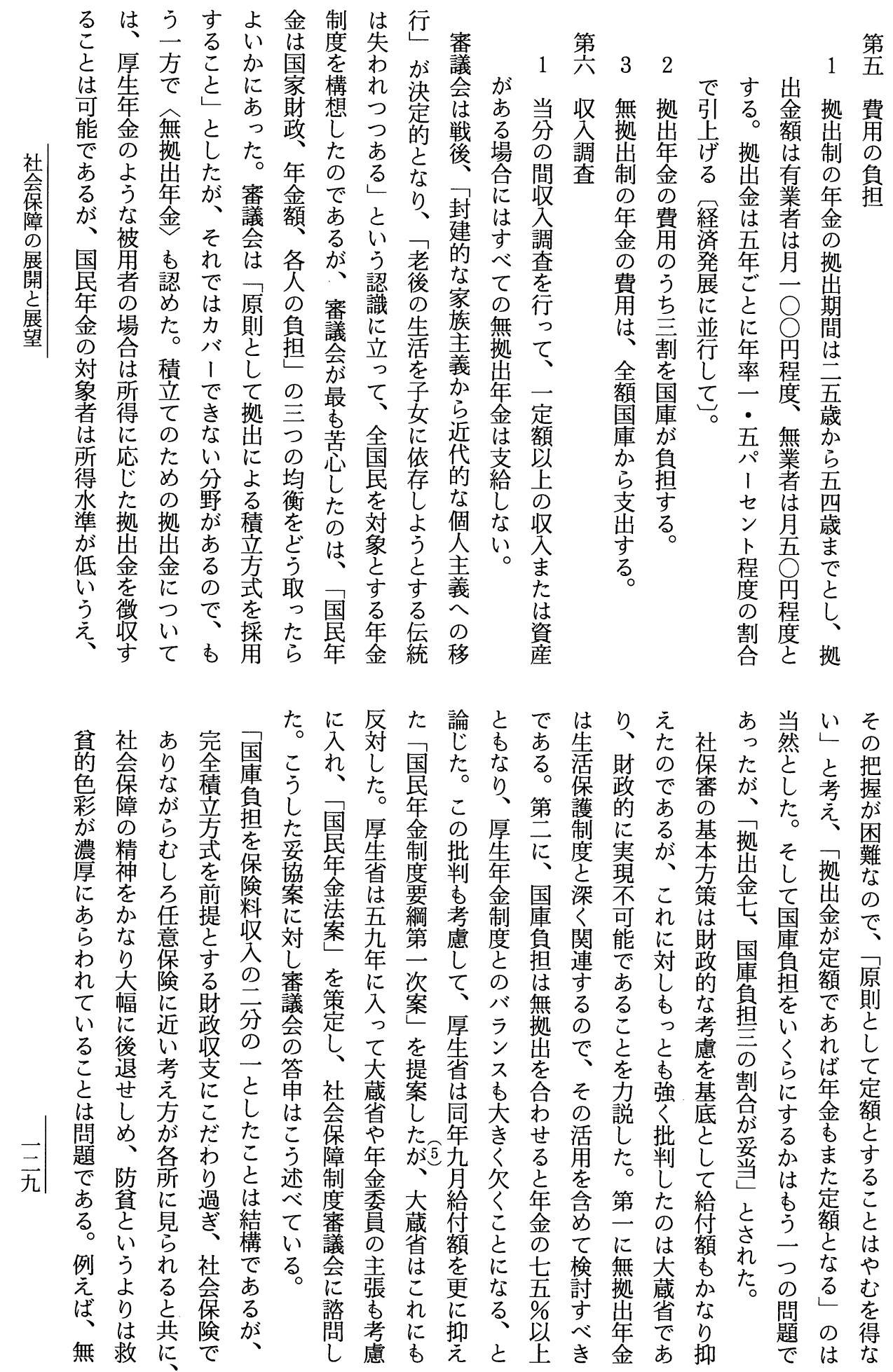


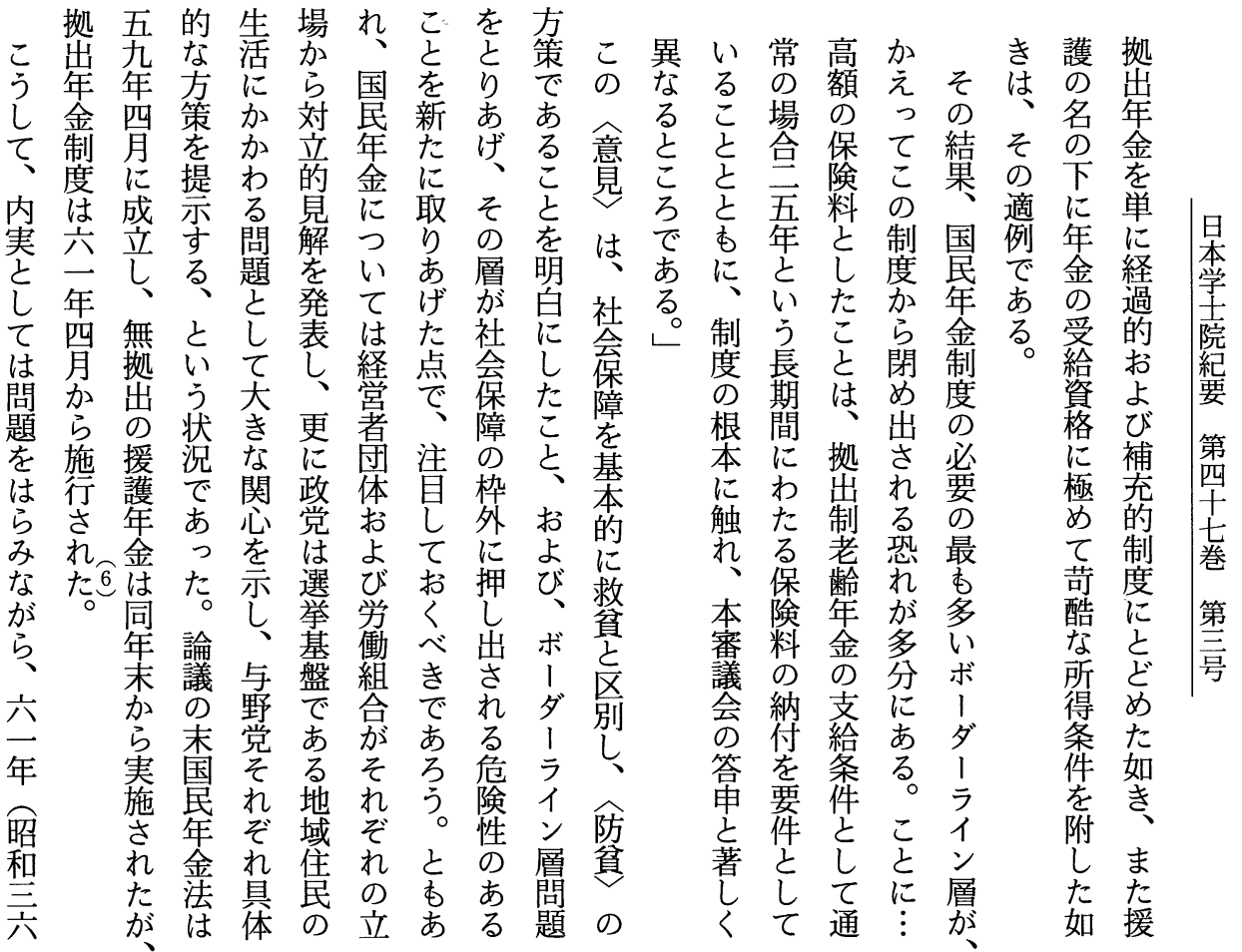

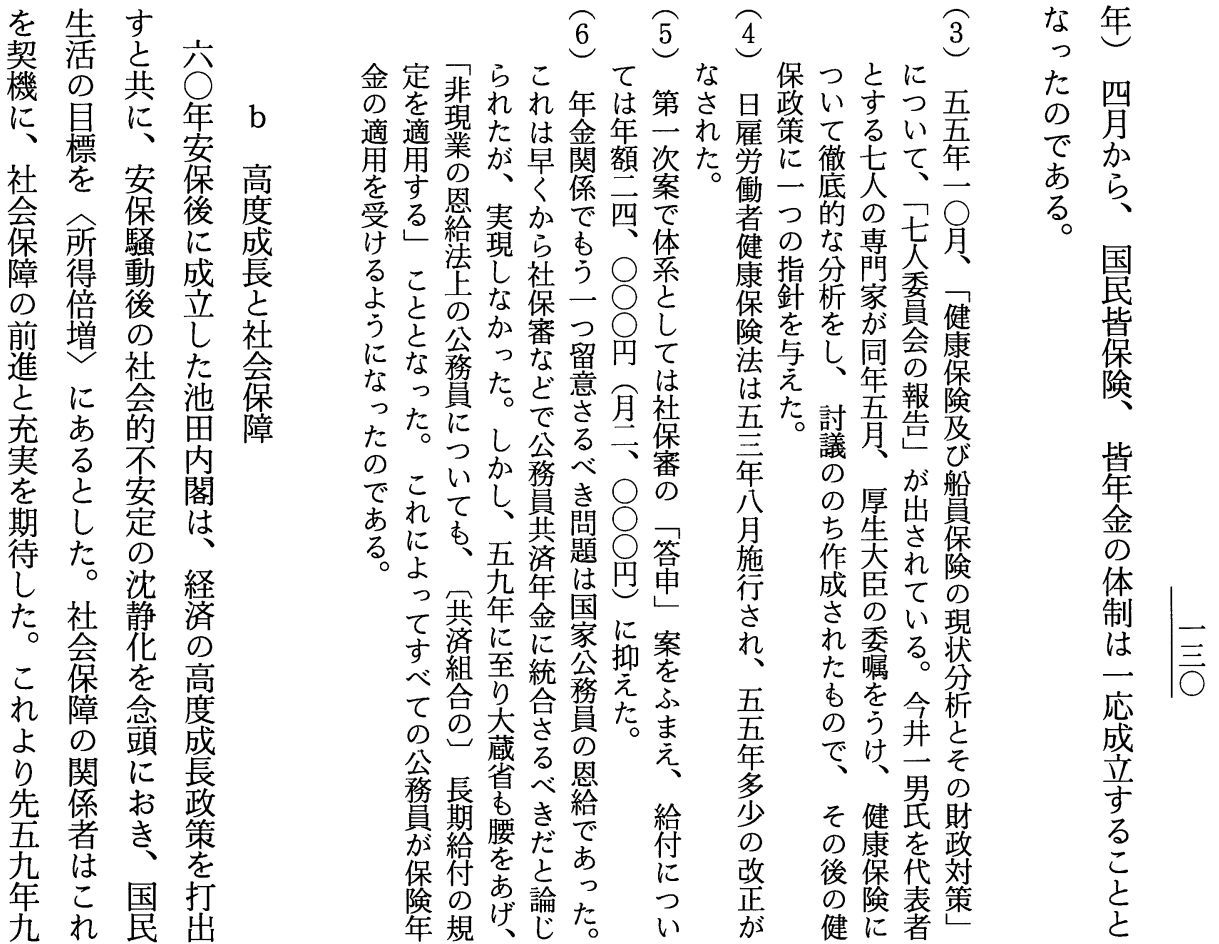



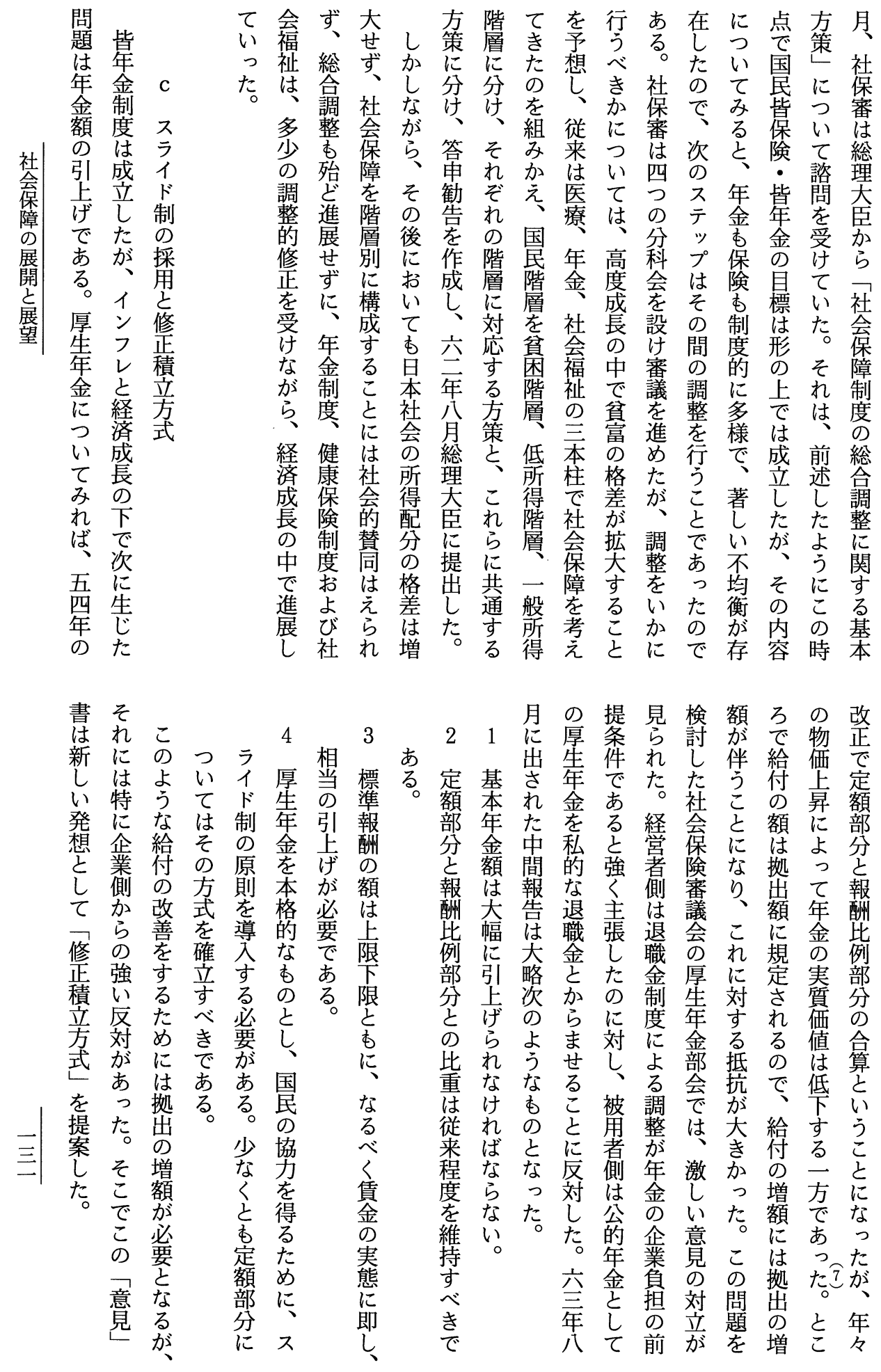


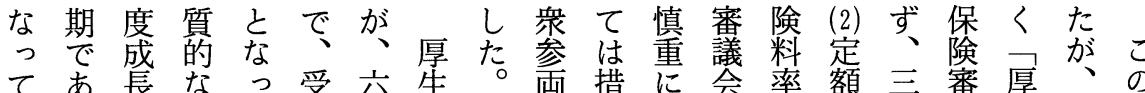

いる老改て給四年院置取合の部者議生財よ

た六続善い者年金年の扱答決分の会年政う

九けはた数は制不徹う申申竞で金当な

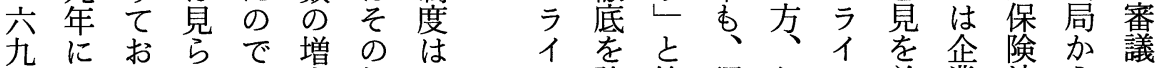

年はりれあ大年五机強答調なド普業法らの

の厚、なるがに年制調拿整ど制記年改の進

改生一か が隻当貝確しし年に等し金齿 ク行

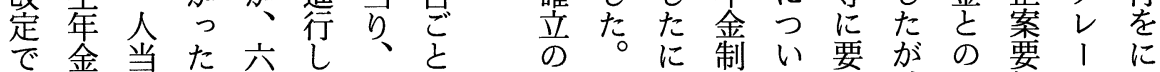

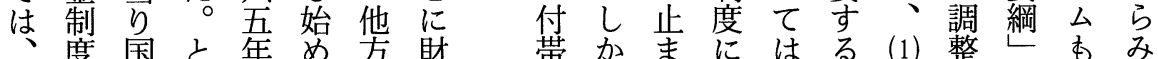

六の底こ改てで政決しりつ意追スでがあな

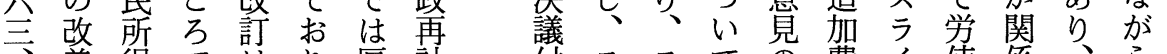

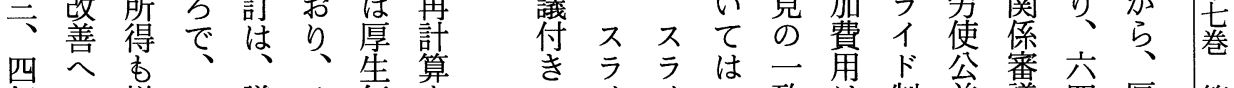

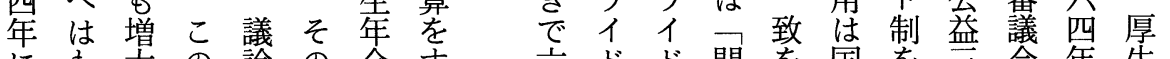

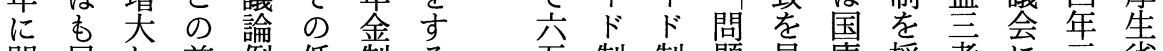

閴早し前倒低制る五制制題見庫摇者に提言省 とき扬らにさす公導国経。担守意出に法

ななり旦終が成に分庫緯社々 見さ至案

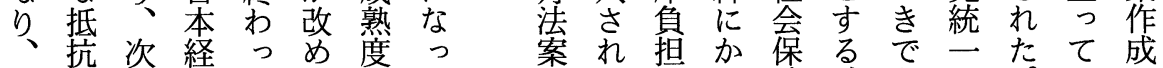

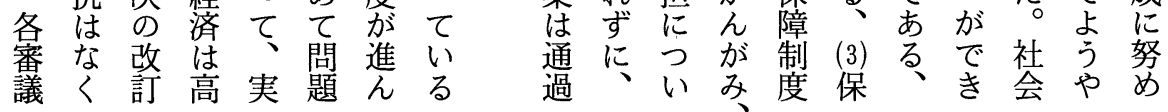

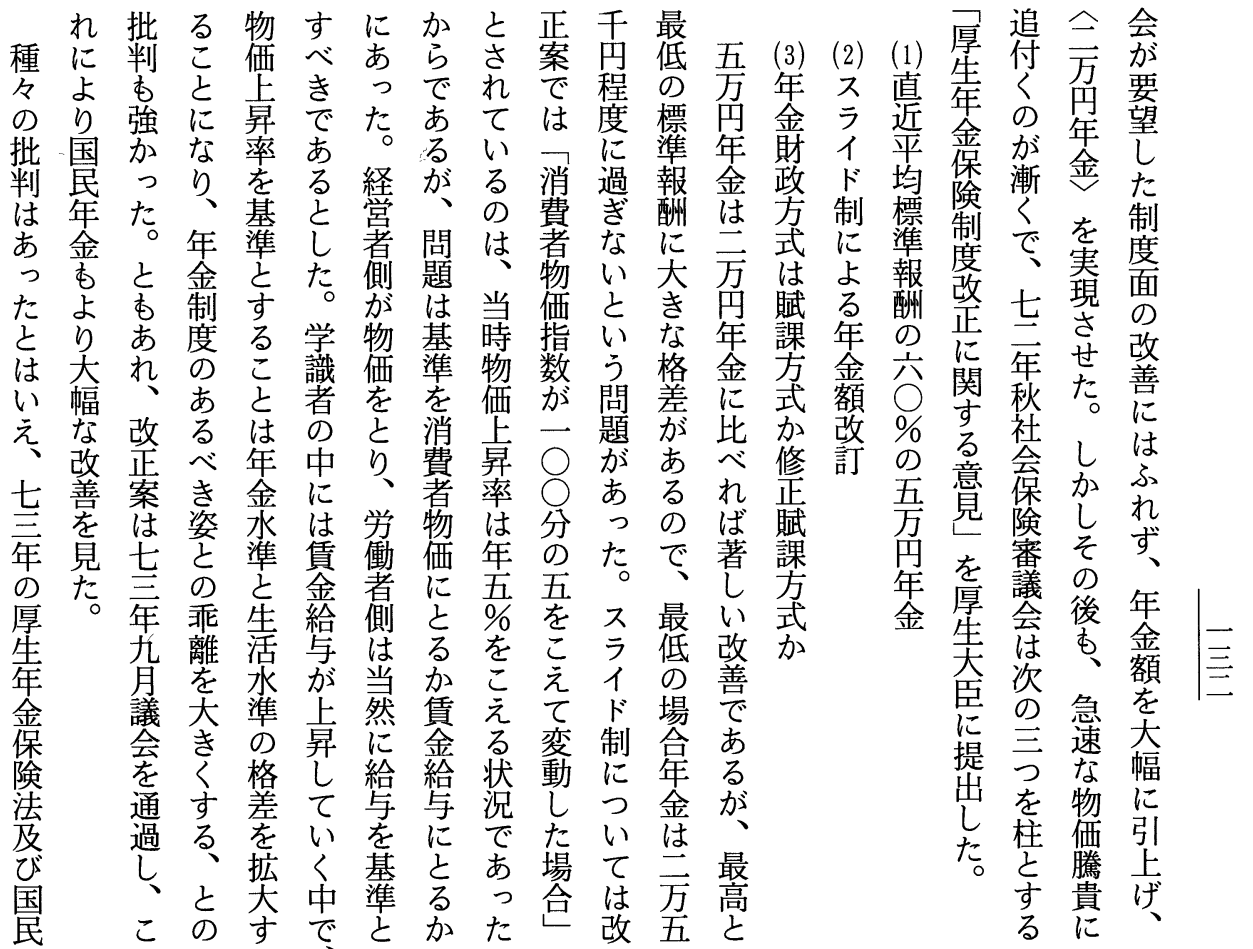


表 1 国民 1 人当たりの社会保障給付費と国民経済

\begin{tabular}{|c|c|c|c|c|c|c|c|}
\hline \multirow{2}{*}{$\begin{array}{l}\text { 年 度 } \\
\text { 昭和45(1970) }\end{array}$} & \multicolumn{2}{|c|}{$\begin{array}{l}\text { 1全当たり社会保障 } \\
\text { 給付 }\end{array}$} & \multicolumn{2}{|c|}{1 人当たり国民所得 } & \multicolumn{2}{|c|}{$\begin{array}{l}\text { 消費者物価指数 } \\
\text { 昭和 } 48 \text { 年 }=100\end{array}$} & \multirow{2}{*}{$\begin{array}{r}\text { 社会保障 } \\
\text { 賏 } \\
\\
5.8\end{array}$} \\
\hline & $\begin{array}{l}\text { 千円 } \\
33.7\end{array}$ & $(60.2)$ & $\begin{array}{r}\text { 千円 } \\
589\end{array}$ & $(67.0)$ & 81.9 & $(77.5)$ & \\
\hline 46(1971) & 37.4 & $(66.8)$ & 627 & (71.3) & 86.5 & (81. 8) & 6.0 \\
\hline $47(1972)$ & 45.5 & $(81.3)$ & 726 & $(82.6)$ & 91.0 & $(86.1)$ & 6.3 \\
\hline $48(1973)$ & 56.0 & $(100.0)$ & 879 & $(100.0)$ & 105.7 & $(100.0)$ & 6.4 \\
\hline $49(1974)$ & 80.4 & $(143.6)$ & 1,018 & (115. 8) & 128. 8 & (121.9) & 7. 9 \\
\hline $50(1975)$ & 104.3 & $(186.3)$ & 1,109 & $(126.2)$ & 142.2 & $(134.5)$ & 9.5 \\
\hline $51(1976)$ & 128.1 & $(228.8)$ & 1,242 & (141.3) & 155.5 & $(147.1)$ & 10.5 \\
\hline $52(1977)$ & 147.6 & $(263.6)$ & 1,365 & (155. 3) & 166.0 & $(157.0)$ & 11.0 \\
\hline $53(1978)$ & 171.2 & $(305.7)$ & 1,492 & (169.7) & 171.6 & $(162.3)$ & 11.8 \\
\hline $54(1979)$ & 188.6 & $(336.8)$ & 1,570 & $(178.6)$ & 179. 8 & $(170.1)$ & 12. 3 \\
\hline $55(1980)$ & 210.2 & $(375.4)$ & 1,704 & (193.9) & 193.9 & (183.4) & 12.7 \\
\hline $56(1981)$ & 232.1 & $(414.5)$ & 1,767 & $(201.0)$ & 201.7 & (190. 8) & 13. 5 \\
\hline $57(1982)$ & 252.3 & $(450.5)$ & 1,827 & (207. 8) & 206.5 & (195.4) & 14. 2 \\
\hline $58(1983)$ & 267.0 & (476. 8) & 1,900 & $(216.2)$ & 210.5 & (199. 1) & 14.5 \\
\hline
\end{tabular}

（注）（ ）内は, 昭和 48 年度を 100 とした場合の指数である。

資料：社会保障給付費は厚生省政策課調心

国民所得は, 経済企画庁「昭和 55 年基準改訂国民経済計算」

消費者物価指数は，総務庁統計局「消費者物価指数年報」

社会保障負担率は国民所得に占める社会保障費の比率

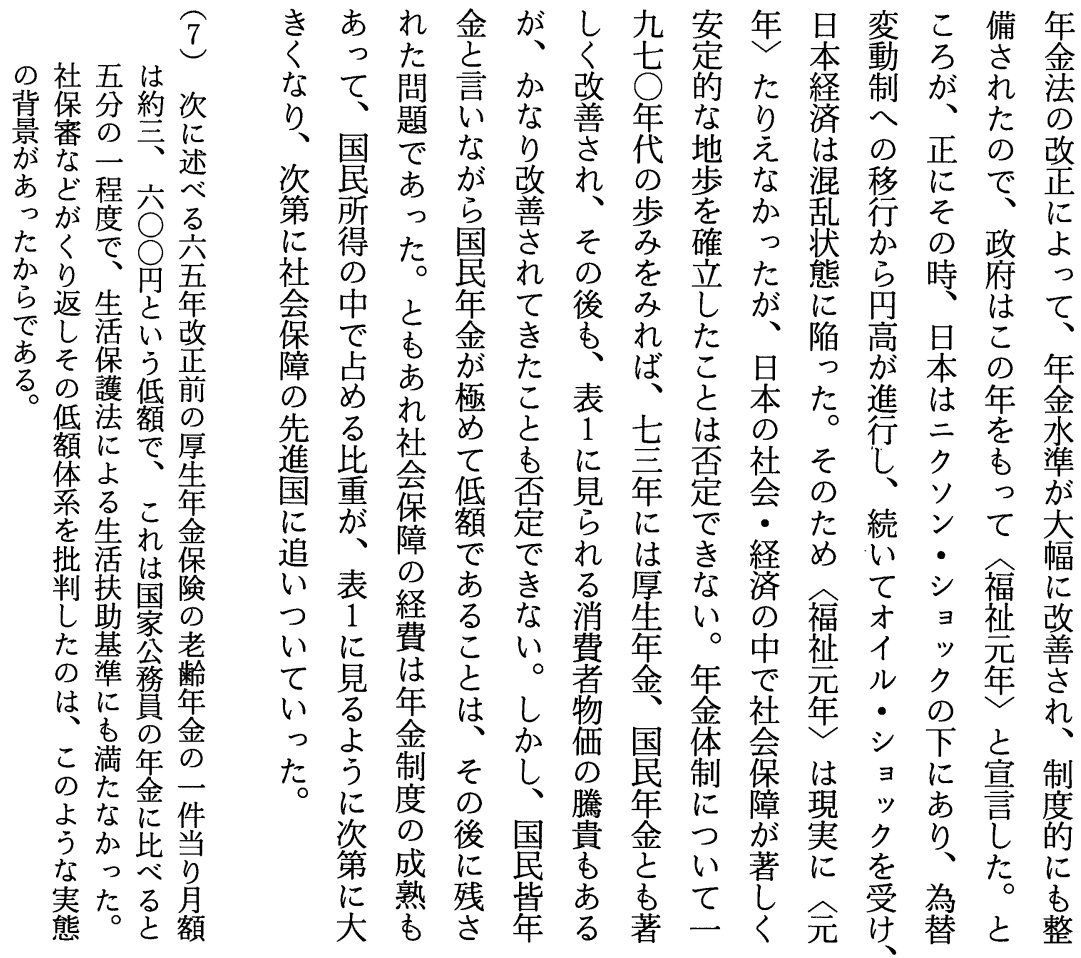




\begin{tabular}{c|c|c}
\multicolumn{2}{c}{ 表 2 } & \multicolumn{2}{c}{ 平均寿命 } \\
\hline & 男子 & 女子 \\
\hline 1947 & 50.1 & 54.0 \\
55 & 63.6 & 67.8 \\
60 & 65.3 & 70.2 \\
65 & 67.7 & 72.9 \\
70 & 69.3 & 74.7 \\
75 & 71.7 & 76.9 \\
80 & 73.4 & 78.8 \\
\hline 厚生省, 簡易生命表
\end{tabular}

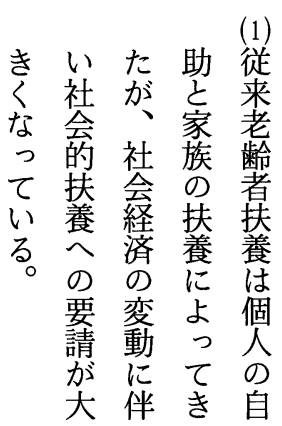

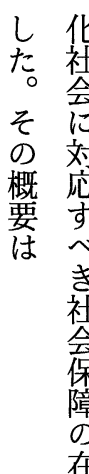

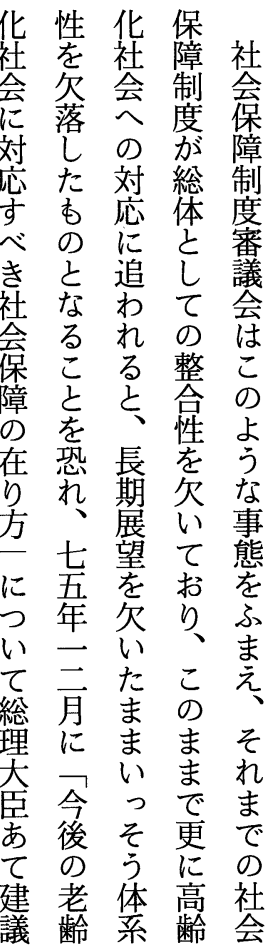

表 3 総人口等年次推移

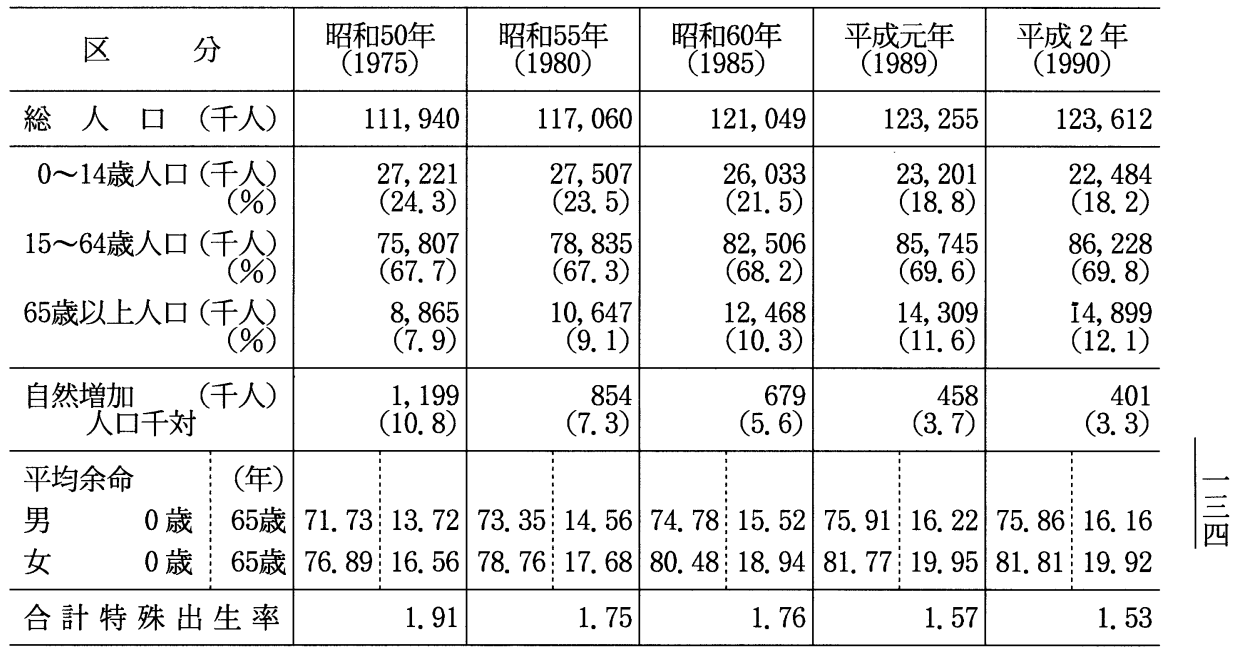

資料：社会保障制度審議会事務局「社会保障統計年報」平成 3 年版 

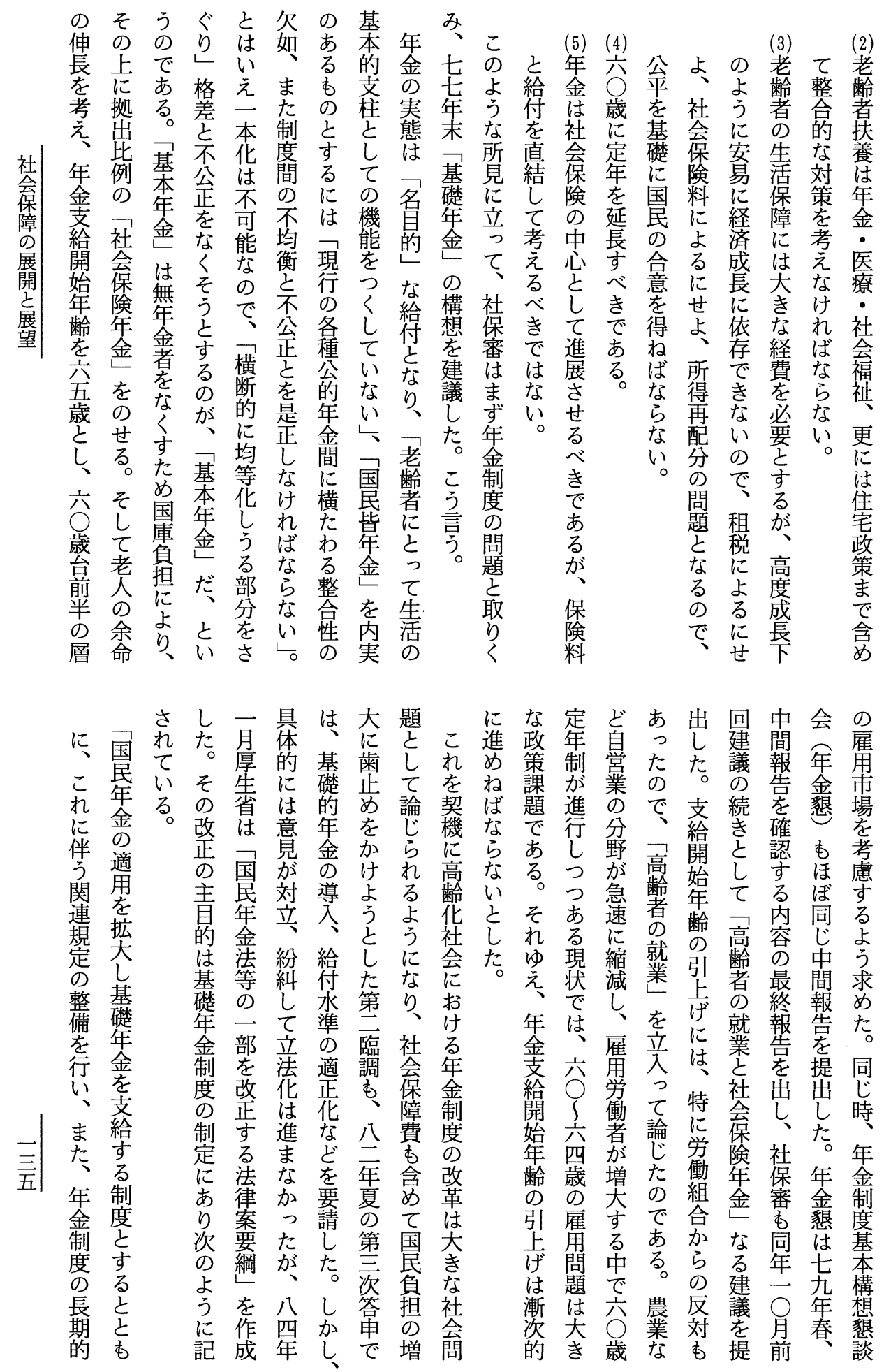


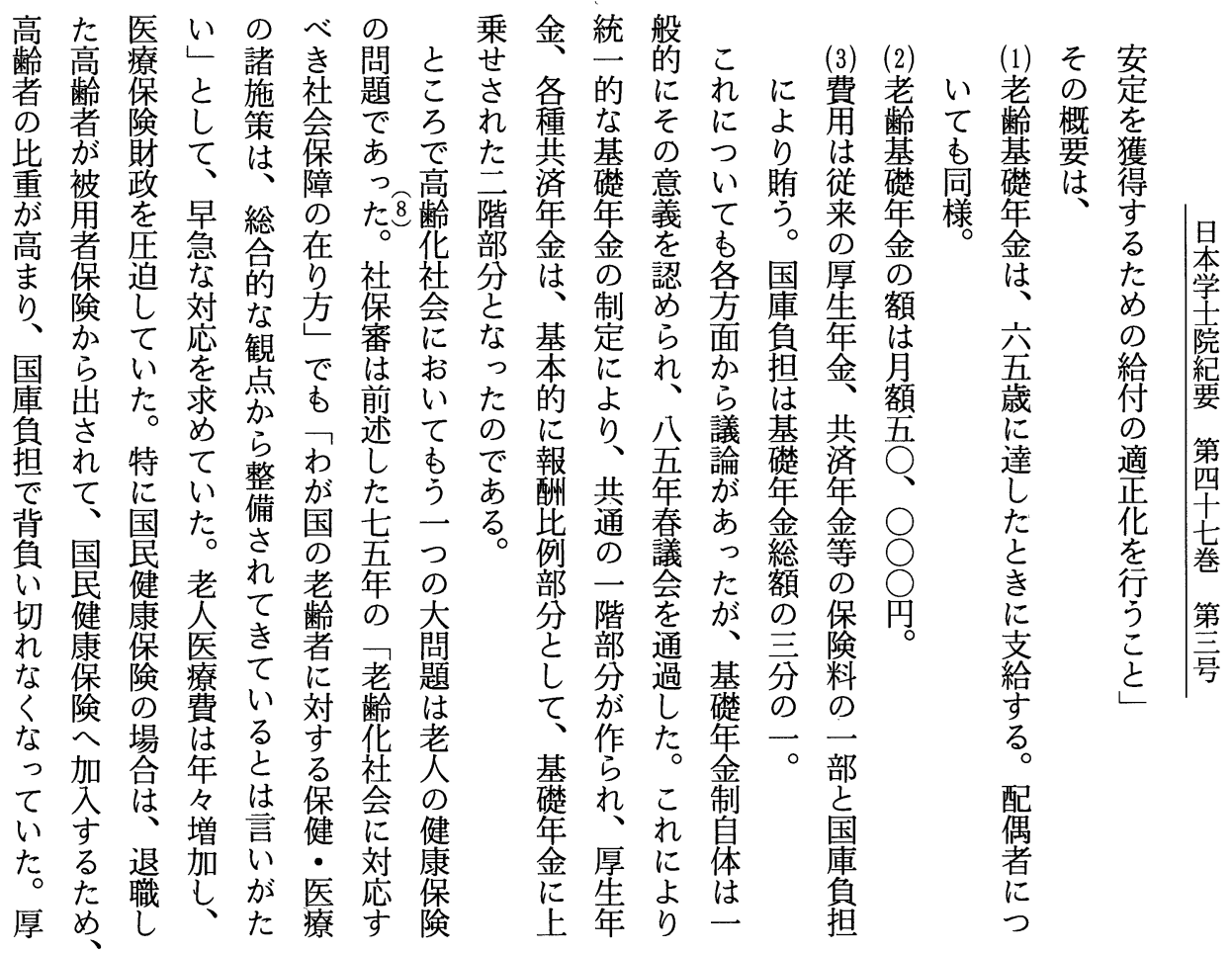

表 4 年齢 3 区分別人口および構造係数（中位推計）

\begin{tabular}{rr|c|c|c|c|c|c|c}
\hline \multirow{2}{*}{ 年 } & \multirow{4}{*}{ 次 } & \multicolumn{4}{|c|}{ 人 口 (単位 1,000 人) } & \multicolumn{3}{c}{ 割 合 (\%) } \\
\cline { 3 - 9 } & & 総 数 & $0-14$ 歳 & $15-64$ 歳 & 65 歳以上 & $0-14$ 歳 & $15-64$ 歳 & 65 歳以上 \\
\hline 平成 2 & 1990 & 123,612 & 22,484 & 86,228 & 14,899 & 18.19 & 69.76 & 12.05 \\
7 & 1995 & 125,263 & 19,993 & 87,116 & 18,154 & 15.96 & 69.55 & 14.49 \\
12 & 2000 & 126,981 & 19,279 & 86,191 & 21,511 & 15.18 & 67.88 & 16.94 \\
17 & 2005 & 128,663 & 20,120 & 84,166 & 24,376 & 15.64 & 65.42 & 18.95 \\
22 & 2010 & 129,450 & 21,247 & 80,936 & 27,266 & 16.41 & 62.52 & 21.06 \\
27 & 2015 & 128,852 & 21,076 & 77,002 & 30,774 & 16.36 & 59.76 & 23.88 \\
32 & 2020 & 126,903 & 19,617 & 75,317 & 31,969 & 15.46 & 59.35 & 25.19 \\
\hline
\end{tabular}

資料：厚生省人口問題研究所「日本の将来推計人口」 


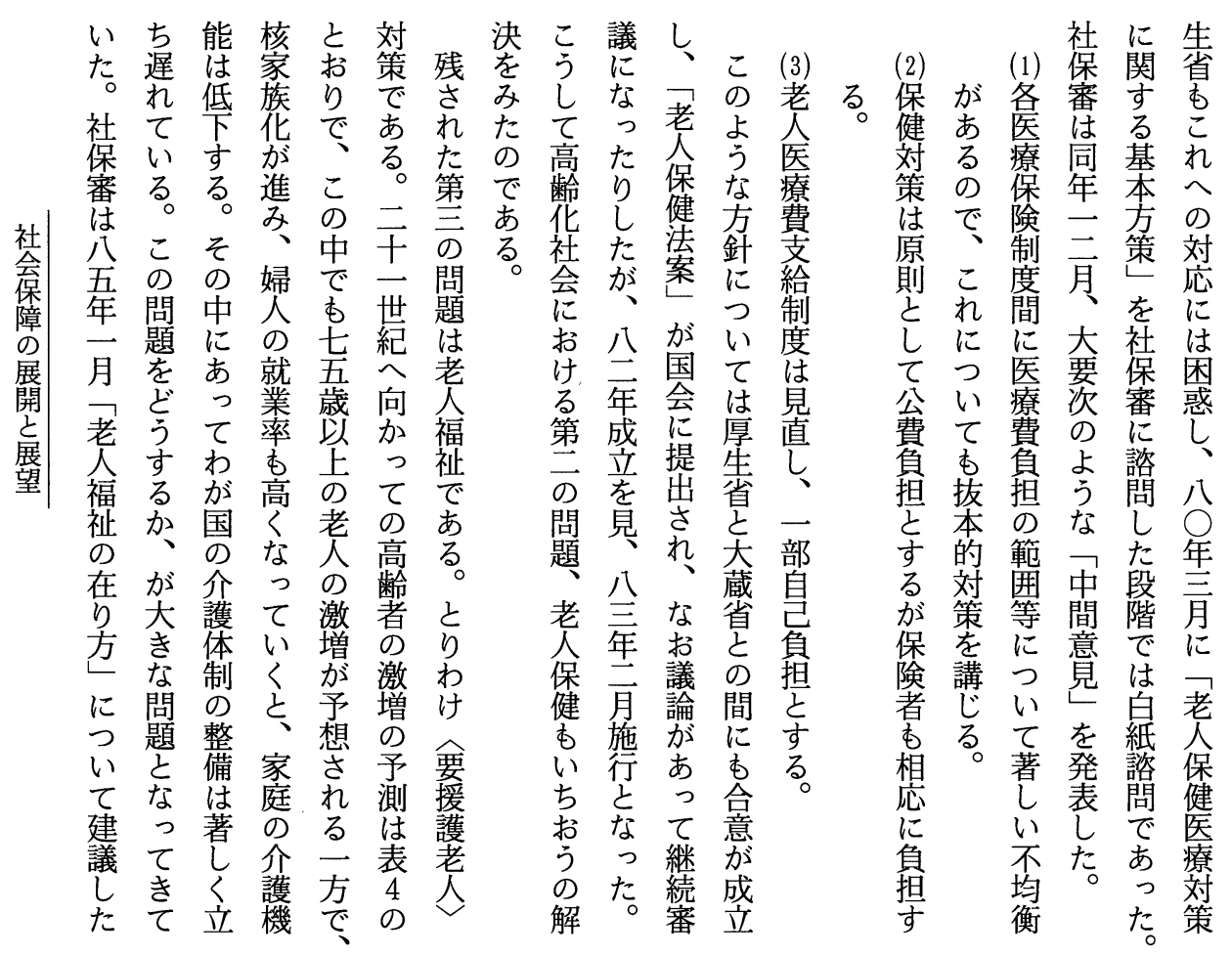

表 5 国民負担率の国際比較单位 \%)

\begin{tabular}{|c|c|c|c|c|c|c|}
\hline 区 分 & (苹成2年度) & $\begin{array}{l}\text { アメリカ } \\
\text { (昭和62) }\end{array}$ & $\begin{array}{c}\text { イギリス } \\
\text { (昭61) }\end{array}$ & $\begin{array}{l}\text { 西ドイッ } \\
\text { (昭62) }\end{array}$ & $\begin{array}{l}\text { フランス } \\
\text { (昭62) }\end{array}$ & $\begin{array}{c}\text { スウェーデン } \\
\text { (昭62) }\end{array}$ \\
\hline \multirow{2}{*}{$\begin{array}{l}\text { 租 税 負 担 率 } \\
\text { 社会保障負担率 }\end{array}$} & 28.3 & 26.4 & 41.9 & 29.9 & 34.1 & 58.1 \\
\hline & 12.1 & 9.9 & 11.4 & 22.4 & 28. 2 & 18.9 \\
\hline 国民負担率 & 40.4 & 36.3 & 53.3 & 52.3 & 62.3 & 77.0 \\
\hline \multirow{2}{*}{$\begin{array}{l}\text { (注) } \\
\text { 老齢人口比率 }\end{array}$} & （昭60） & （昭60） & （昭60） & （昭60） & （昭60） & （昭60） \\
\hline & 10.3 & 12.0 & 15.1 & 14.5 & 12.8 & 16.9 \\
\hline \multirow{2}{*}{ （65歳以上人口） } & (平12) & (平12) & (平12) & (平12) & （平12） & (平12) \\
\hline & 16. 3 & 12.0 & 15.3 & 16. 7 & 14.7 & 17. 2 \\
\hline
\end{tabular}

三

（注） $\left[\begin{array}{l}\text { 過去 } 15 \text { 年間の老齢人口比率の上昇 }: 3.2 \% \text { ポイント }(7.1 \% \rightarrow 10.3 \%) \\ \text { 今後 } 15 \text { 年間の老齢人口比率の上昇 : } 6.0 \% \text { ポイント }(10.3 \% \rightarrow 16.3 \%)\end{array}\right]$

資料 : 年金研究所「剘政と社会保障の諸問題」 


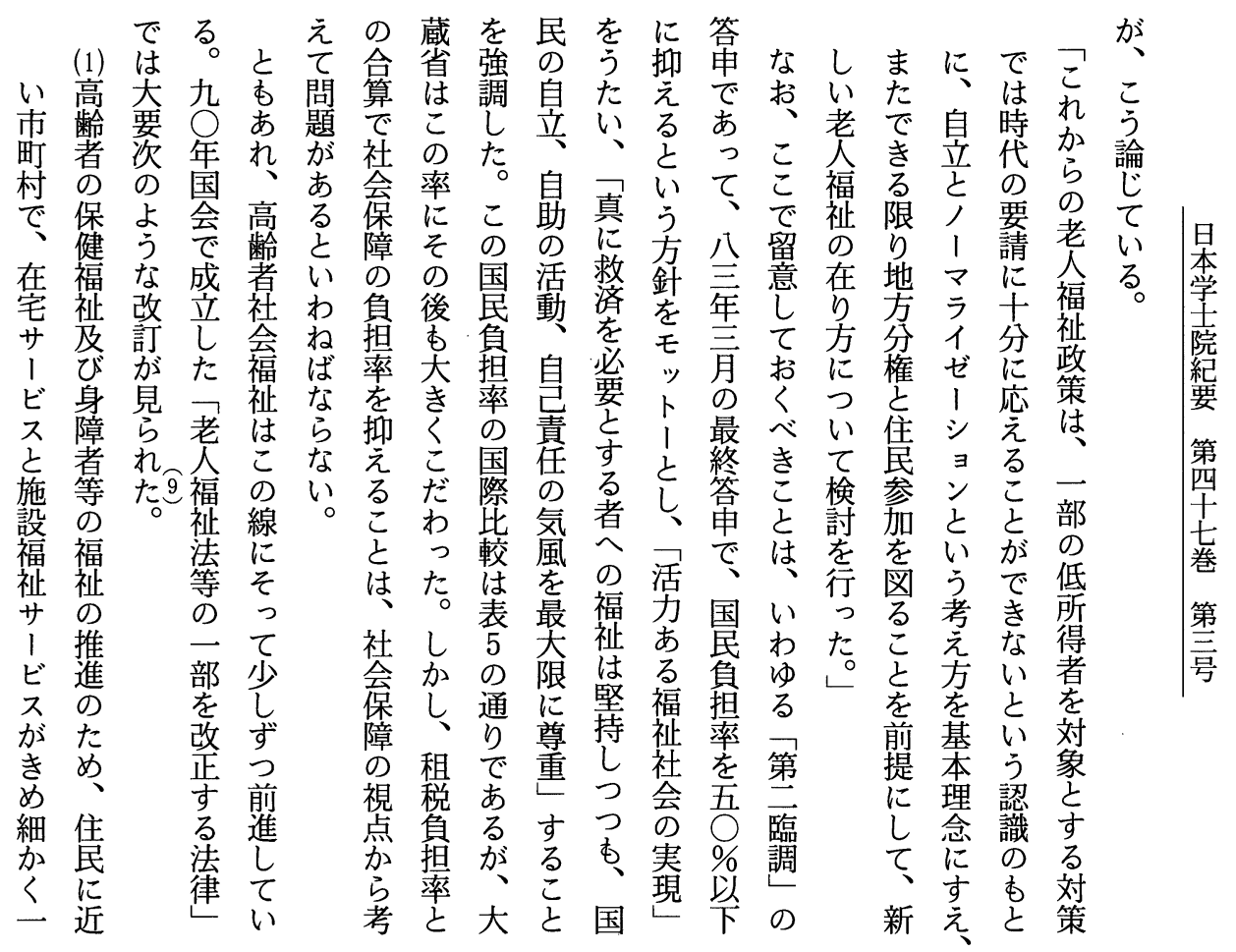

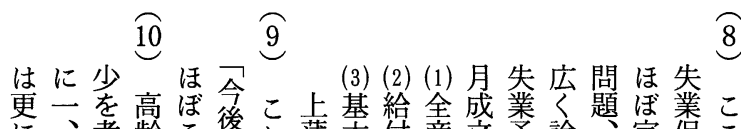

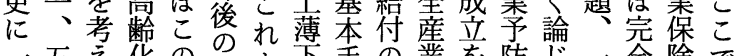
二五元化の社市手の業を防じ五全険て

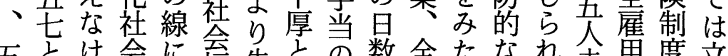

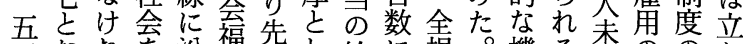

言な机考沿福先し給に嫢。機る満のの古 にりば考口䄈社た付つ模そ能上湡状改入

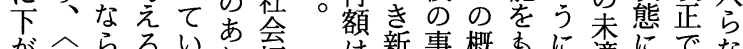
が全なるい占場た方福中新事概あに適にでな

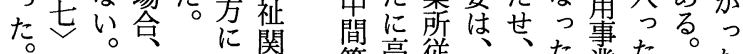

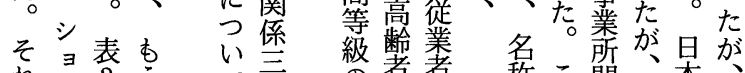

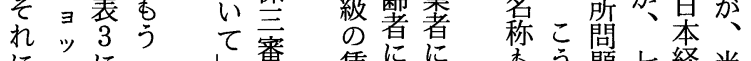

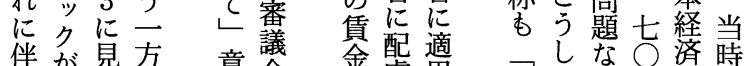

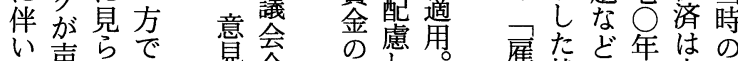

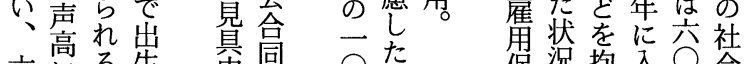
六高る殅基局

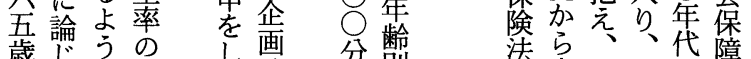

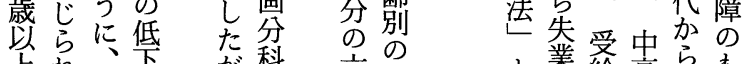

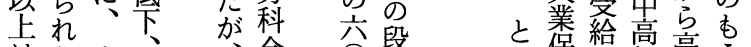
はた出低会䁂保答高高う

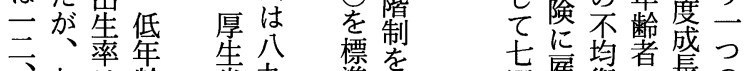

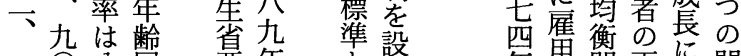

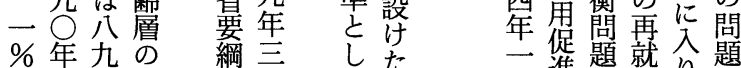
とに年減絧局、た。進題就り、題

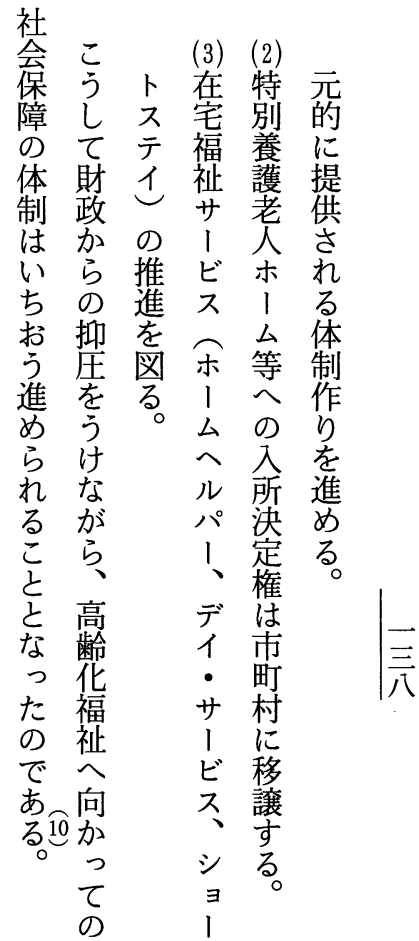




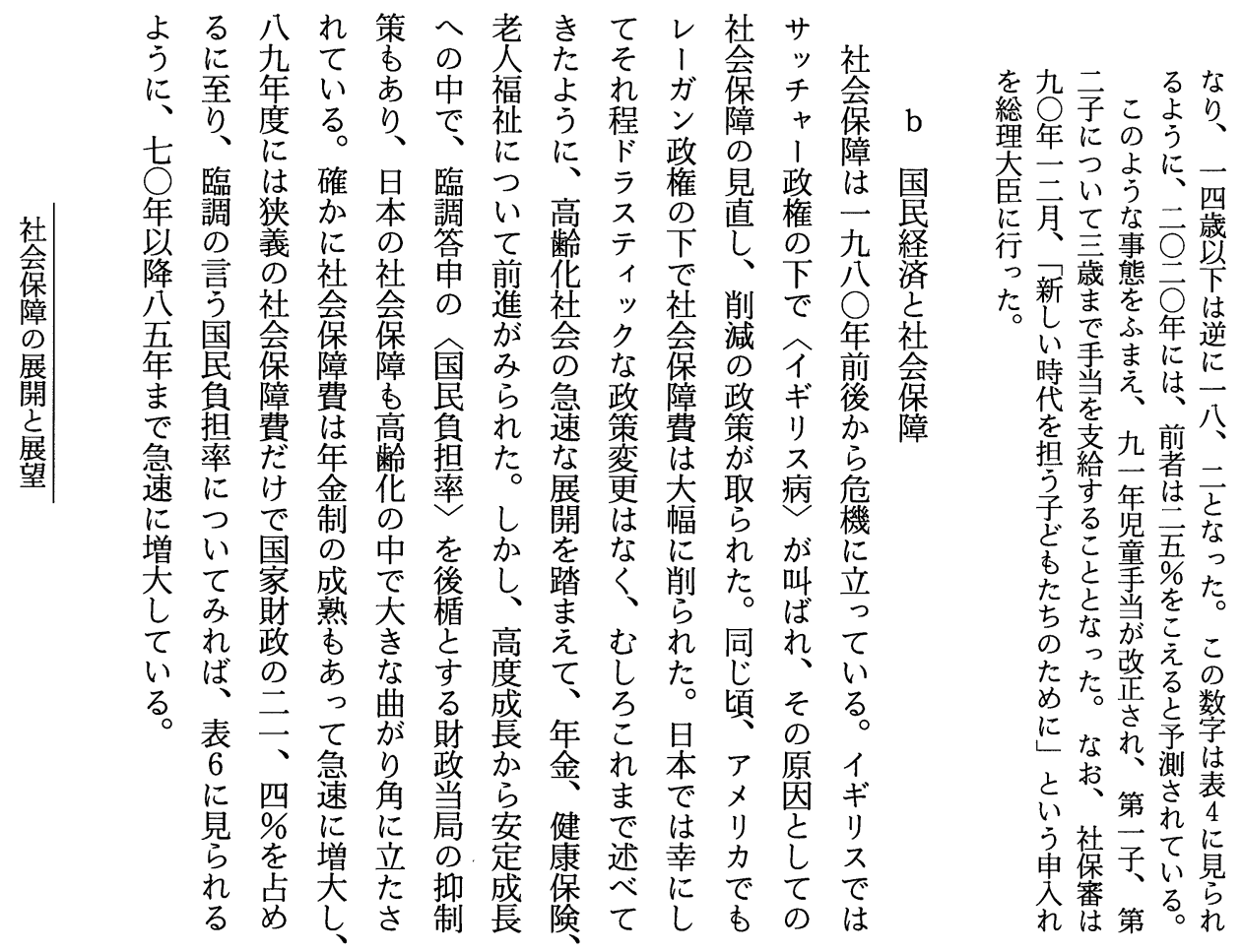

表 6 国民負担率（租税負担率及び社会保障負担率）の推移 （単位 \%)

\begin{tabular}{c|c|c|c|c|c|c}
\hline \multirow{2}{*}{ 年 度 } & \multirow{2}{*}{ 国民負担率 } & \multirow{2}{*}{ 租税負担率 } & \multicolumn{4}{|c}{ 社会保障負担率 } \\
\cline { 5 - 7 } & & & 医 療 & 年 金 & その他 \\
\hline 1970年 & 24.3 & 18.9 & 5.4 & 2.4 & 2.4 & 0.7 \\
75 & 25.8 & 18.3 & 7.5 & 3.0 & 3.6 & 0.9 \\
80 & 31.3 & 22.2 & 9.1 & 3.4 & 4.8 & 0.9 \\
85 & 34.6 & 24.1 & 10.5 & 3.7 & 5.9 & 0.8 \\
87 & 37.3 & 26.6 & 10.7 & 3.8 & 6.0 & 0.9 \\
88 & 38.2 & 27.5 & 10.7 & 3.8 & 6.0 & 0.9 \\
89 & 38.7 & 27.9 & 10.8 & 3.8 & 6.1 & 0.9 \\
\hline
\end{tabular}

表 7 所得再分配による不平等是正効果 (ジニ係数) の年次比較

\begin{tabular}{|c|c|c|c|c|c|}
\hline \multirow[t]{2}{*}{ 調査年次 } & \multirow{2}{*}{$\begin{array}{l}\text { 当初所得 } \\
\text { ジ二係数 }\end{array}$} & \multicolumn{2}{|c|}{ 再分配所得 } & \multicolumn{2}{|c|}{ 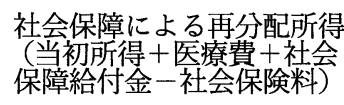 } \\
\hline & & ジ二係数 & 改 善度 & ジ二係数 & 改 善 度 \\
\hline 昭和56年 & 0.3491 & 0.3143 & 10.0 & 0.3317 & 5.0 \\
\hline 59 & 0.3975 & 0.3426 & 13. 8 & 0.3584 & 9.8 \\
\hline 62 & 0.4049 & 0.3382 & 16.5 & 0.3564 & 12.0 \\
\hline
\end{tabular}

資料：表 6,7 とも厚生省大臣官房政策課 


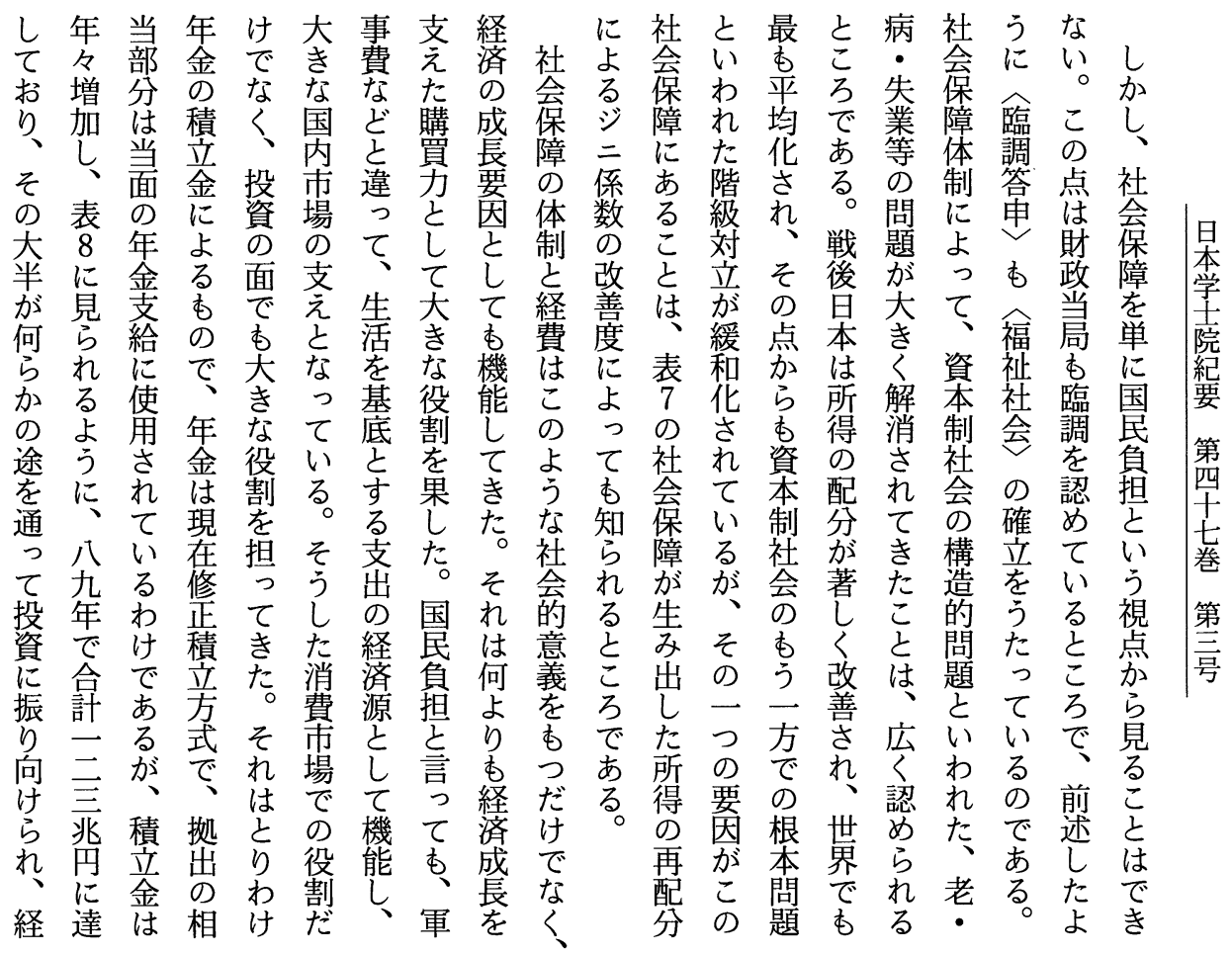

表 8 公的年金積立金状況年度末現在（単位 百万円）

\begin{tabular}{|c|c|c|c|c|c|}
\hline 区 & 昭和60年度 & 61 & 62 & 63 & 平成元年度 \\
\hline 合 & $85,987,592$ & $94,728,604$ & $103,509,533$ & $113,851,837$ & $123,159,303$ \\
\hline 厚 生 年 金 保 険 & $50,782,832$ & $55,281,343$ & $59,963,820$ & $\mid 65,612,647$ & $70,217,477$ \\
\hline 厚 生 年 金 基 金 & $12,348,188$ & $14,488,300$ & $19,908,800$ & $19,649,400$ & $22,487,800$ \\
\hline 民 & $2,593,854$ & $2,915,820$ & $3,344,259$ & $3,665,487$ & $3,946,190$ \\
\hline 船 & 394,223 & 428,612 & 62,753 & 62,650 & 61,580 \\
\hline $\begin{array}{c}\text { 国家公務員等共斎組合 } \\
\text { (各首庁組合) }\end{array}$ & $4,030,279$ & $4,390,496$ & $4,703,705$ & $5,074,874$ & $5,395,551$ \\
\hline $\begin{array}{c}\text { 国家公務員等共斎組合 } \\
\text { (通組) }\end{array}$ & $1,978,430$ & $2,000,481$ & $2,096,033$ & $2,090,049$ & $2,026,528$ \\
\hline 地方公務員等共済組合 & $11,728,080$ & $12,887,280$ & $13,902,374$ & $14,933,940$ & $16,068,854$ \\
\hline 私立学校教職員共済組合 & $1,040,711$ & $1,154,363$ & $1,269,501$ & $1,414,825$ & $1,561,256$ \\
\hline 農林漁業団体職員共済組合 & $1,090,995$ & $1,181,909$ & $1,258,288$ & $1,347,965$ & $1,394,067$ \\
\hline
\end{tabular}

資料：社会保障制度審議会「社会保障統計年報」平成 3 年版 

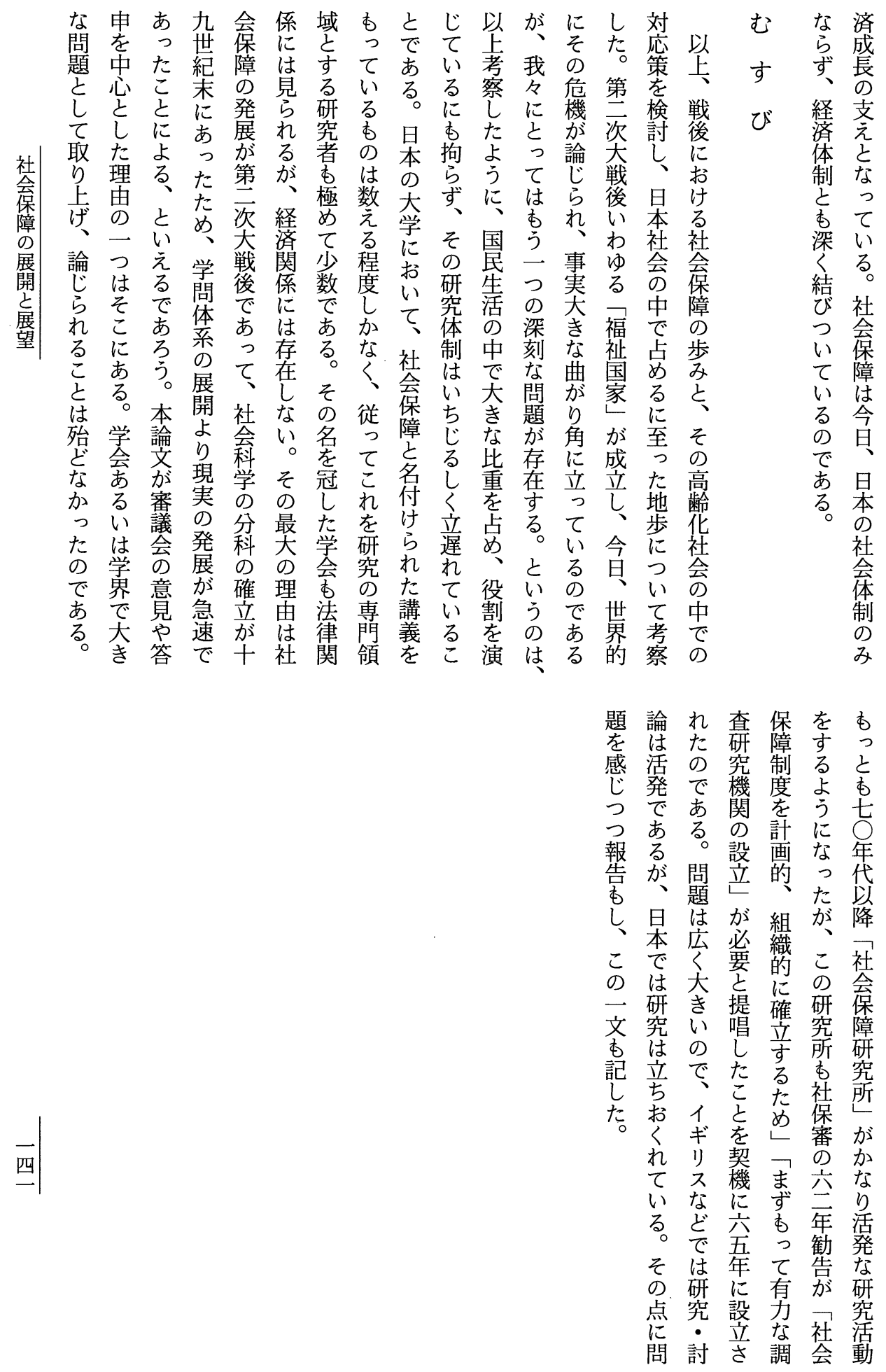
economic problems. But we must keep in mind the stability of nation's life sustained by the development of social security system has been the essential background of economic growth without serious social confusion. 


\title{
Progress and Prospect of Social Security in Japan
}

\author{
Mikio Sumiy A, M. J. A.
}

Social security system in Japan was formulated after the Second World War, in almost the same way as in European countries, though a little later. The Social Security Council which was organized in 1949 by the instruction of GHQ, proposed the Recommendation on Social Security System in 1950. Its fundamental ideas were based on "Social Insurance and Allied Services" (1942) by Lord Beveridge, and it functioned as the basic criterion for the development of social security in Japan. In those days Japan was under social chaos and poverty, but the Council advocated "it would be absolutely necessary to make start the social security and if neglecting to enforce it to some extent, the government could not fulfill her responsibility for urgent social unrest." The ground for this advocate was the new Japanese Constitution which was enacted after the Second World War. The Constitution prescribes as follows: "Every nation has right to live the lowest level of healthy and cultural life" and "the state should make efforts to promote social welfare, social security and public health in every living field."

Nevertheless, social security system had not developed up to the middle of 1950 s because of economic difficulties. It began to progress after the curtain on a scene of economic development was raised. In 1961, the systems of insurance and pension coverage for whole population were implemented.

However, those systems were congeries of conventional health insurance and pension systems and had not been unificated, so that it was necessary to adjust differences of various systems. But the problems have been unsolved up to the present, though revised to some extent.

Later on, pension system sliding up according to the rise of wages and salary level was adjusted under rapid economic growth and inflation; and the contents of social security have been made better by and by .

Then, new serious problem emerged since the middle of $70 \mathrm{~s}$. The rapid population aging has been developing and it began to exert vital influence upon social security system. To cope with such problem, the basic pension system common to whole nation was inaugurated in 1985; and as for the health insurance for the aged the Health and Medical Service Law for the Elderly was implemented in 1983.

Such countermeasures, on the other hand, increased the financial burden, and the future of social security involves inevitably very serious social and 